\title{
$7 \varepsilon$.
}

نموذج مقترح لتقييم إختبار ات القبول الرياضية بكلية التربية الرياضية بنين جامعة الأزهر

\section{'م.د / محمد نبهيل مسعد عبده عوضز}

مقدمة البحث:

تعد كليات التزبية الرياضية من المنظمات التربوية التي تمد المجتمع بالمتخصصـين

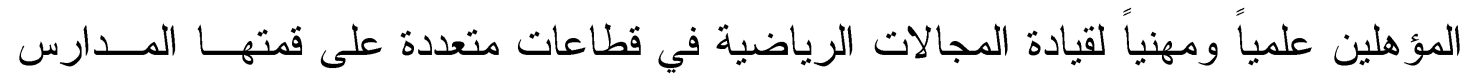

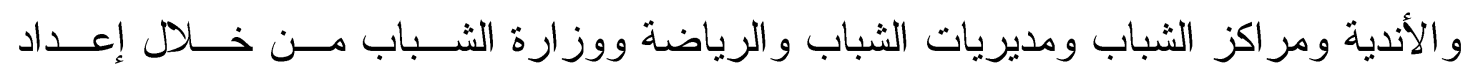
وتخريج كو ادر يقع على عاتقهم مسئولية النهوض بالمجال الرياضي بما بتتاسب مع طبيعــة

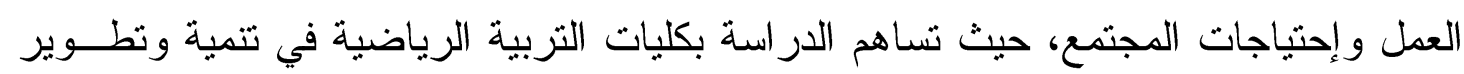

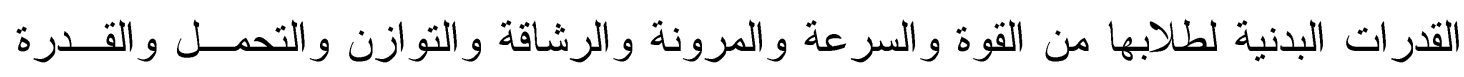
و التو افق العضلي العصبي و إكتساب المهار ات الكافية لأداء مختلف الأنشطة الرياضية بالقــدر الذي يمكنهم من تدريسها وتدريبها و إدارتها بعد التخرج. وتتطلب الدر اسة بكليات التربية الرياضية طبيعة خاصة من إستعدادات وقدرات بدنية ومهارية وعقلية ومعرفية ونفسية وقيادية لدى طلابها تمكنهم من الوفاء بو اجباتهم الدراســية

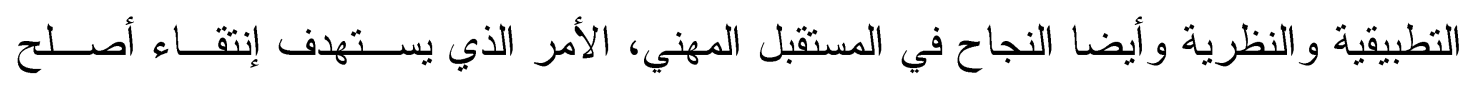

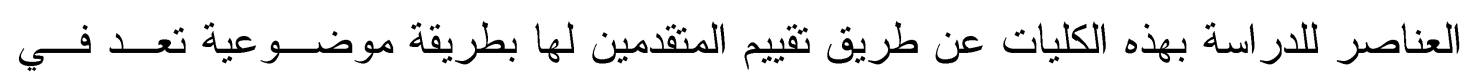
صورة إختبار ات القبول بكليات التربية الرياضية، و التي يمكن من خلالها التتبؤ بمدى نجاحهم في تحقيق أهداف العملية التعليمية بكفاءة وفاعلية.(1) وتتكون إختبار ات القبول بكليات التربية الرياضية من عدة إختبار ات طبية وقو اميــة

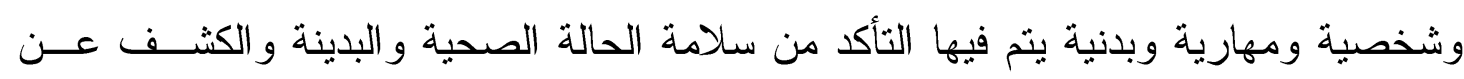
عيوب و إنحر افات القو ام والتحقق دن تو افر الصفات و المعايير الواجب تو افرها لقبول الطلاب

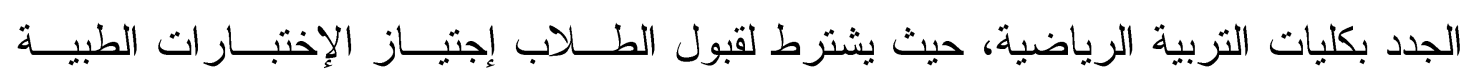
و القو امية و الشخصية ثم إجتباز الإختبار ات المهارية و الرياضية بنسبة نجاح ، بـ مأكثر ثقيم

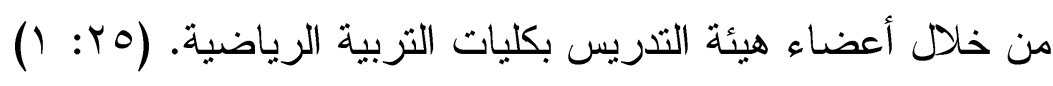

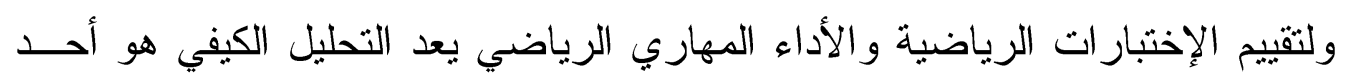

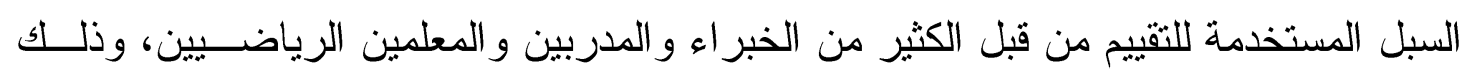
لإسهامه في فهم الأداء من خلال إعتماده على الكشف عن أخطاء أداء الفرد أو الفريق، حيث

* مدرس بقسم علوم الحركة الرياضية- كلية التزبية الرياضية بنين- جامعة الأزهر. 
يستخدم في تقييم الأداء الحركي بخصم أو إضافة درجات وفقاً لإتقان اللاعب أو الطالب فنيات

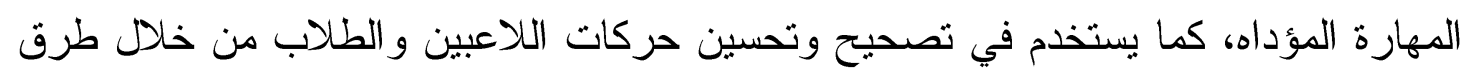

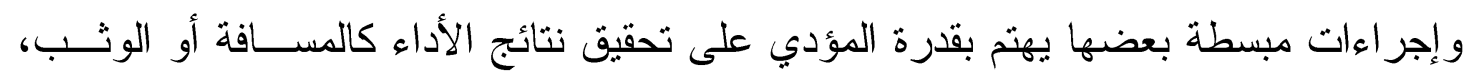

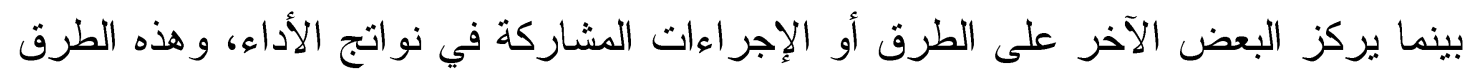

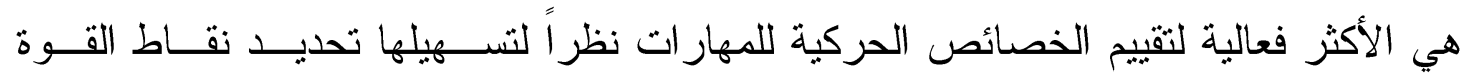

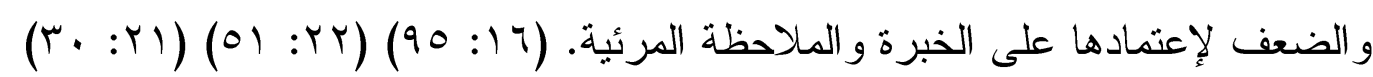

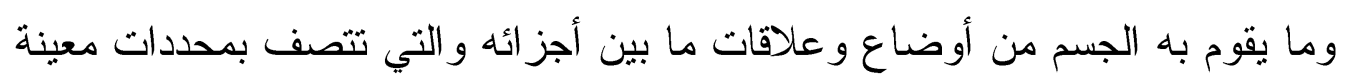

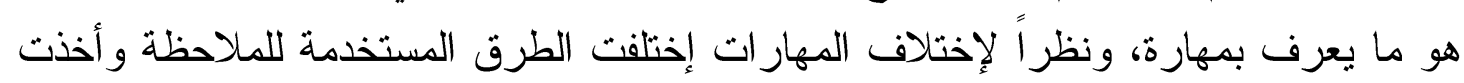

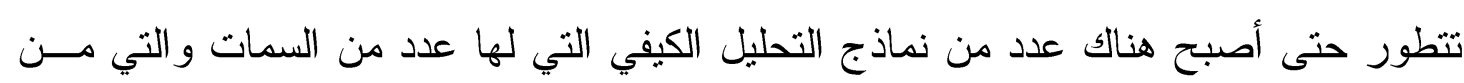

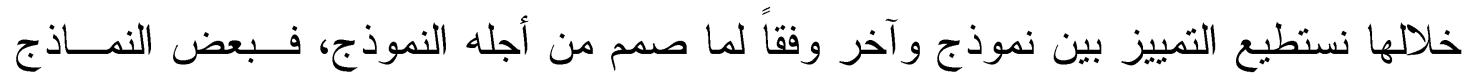

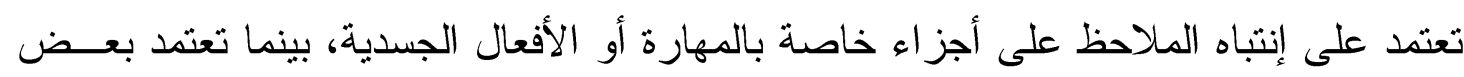

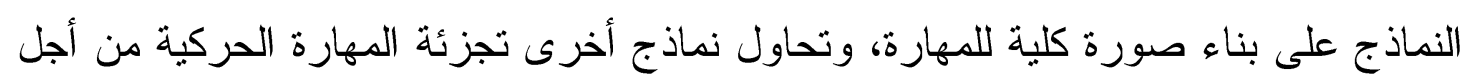

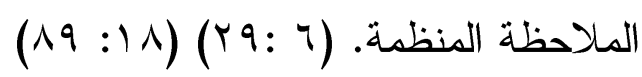

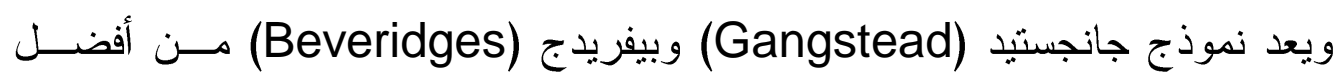

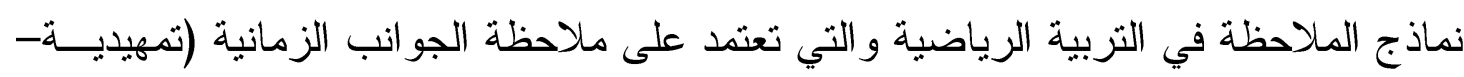

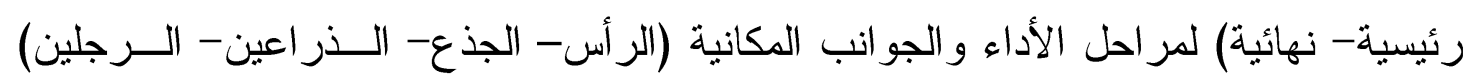

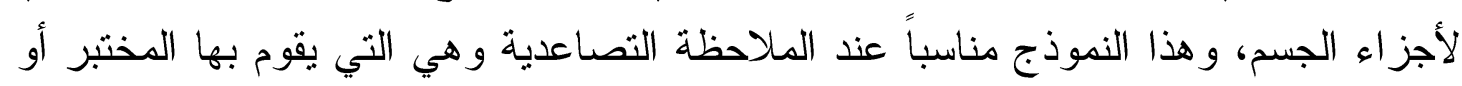

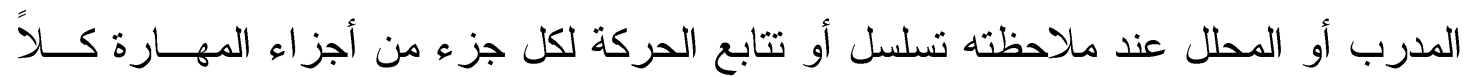

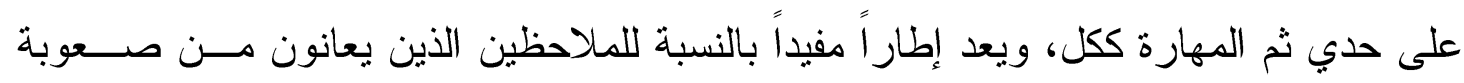

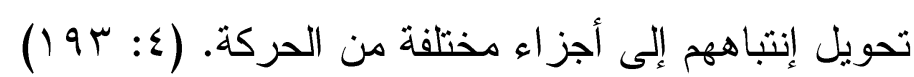

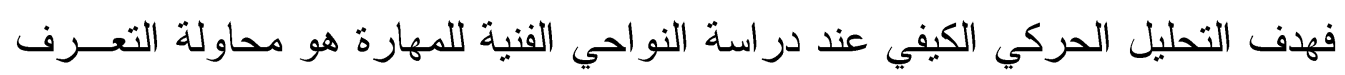

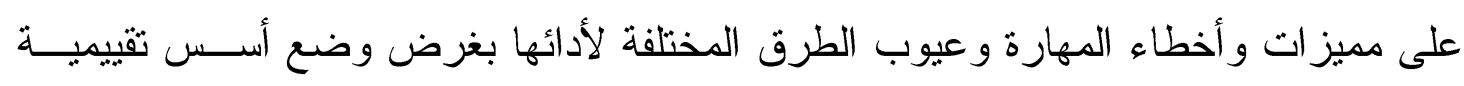

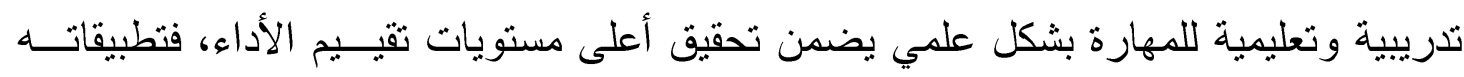
يكون لها تأثير ات فعالة في تحسين الأداء وتصحيح الأخطاء. (1) (1: .9. مشكلة البحث :

من خلال مشاركة الباحث في إختبار ات القبول بكلية التربية الرياضية بنـين جامعسة

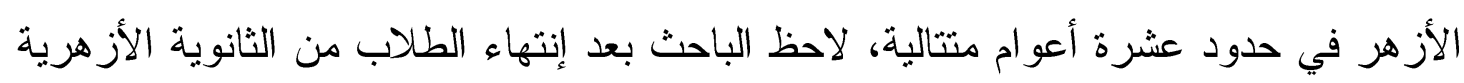
ودراستهم لأكثر من عشرين مادة دراسية وتغير محتوي المو اد الدراسية إلى الأصعب مقارنة الأنة 
بالسنوات السابقة، الأمر الذي يفرض على الطالب الكثير من المذاكرة لأكبر عـدد ســاعات

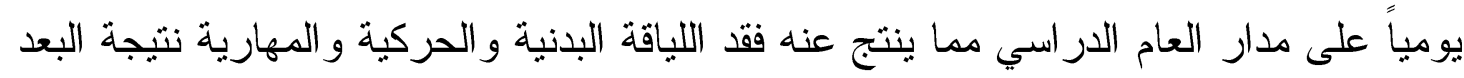

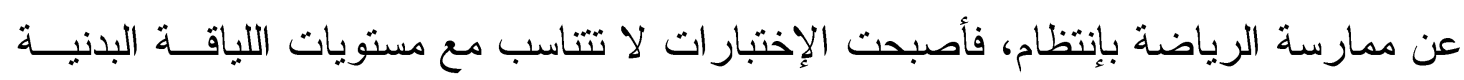
و الحركية و المهارية للطلاب المتقدمين.

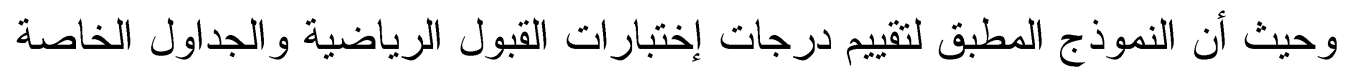

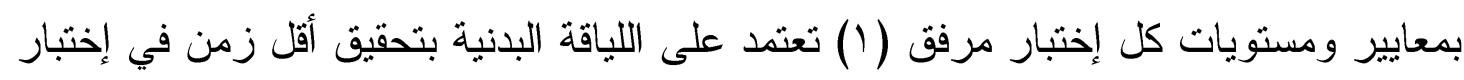

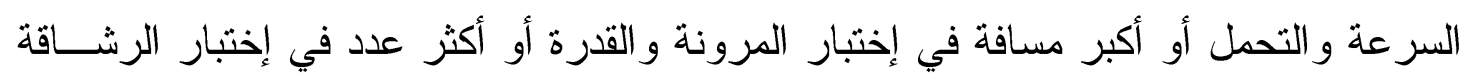

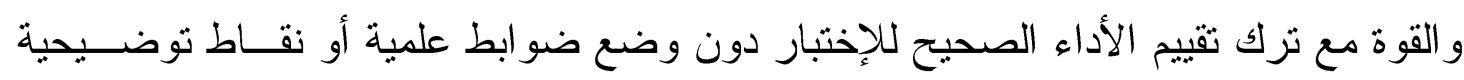
لتحديد الدرجات.

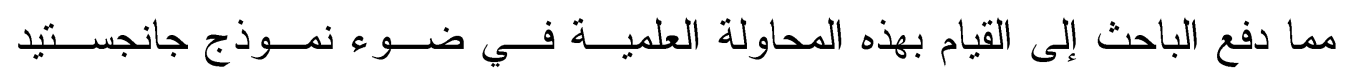

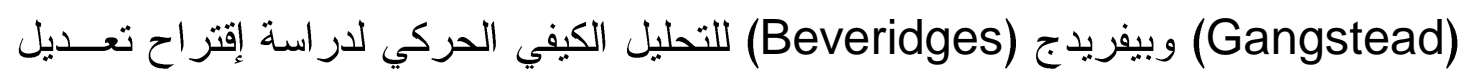

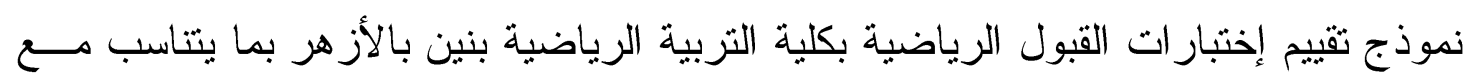

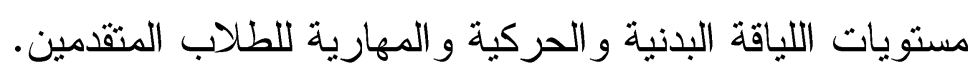

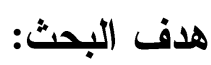

هدف البحث هو الوقوف على تحديد وصفي علمي موضوعي دقيق للحالــة البدنيــة

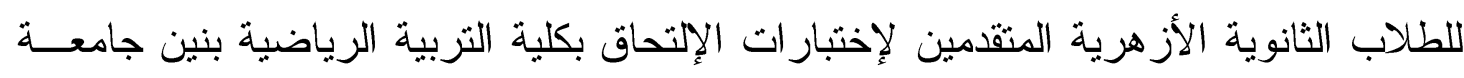

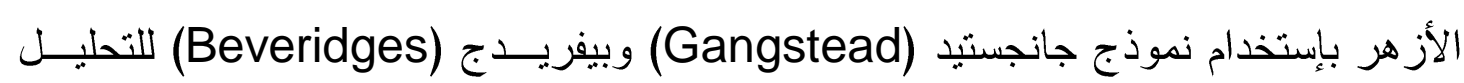

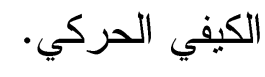
تساؤلات البحث:

1- ما وصف المراحل الفنية لإختبار ات القبول الرياضية بكلية التربيــة الرياضـية بنـين

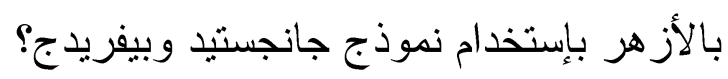

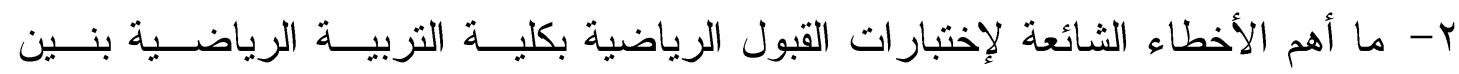
بالأزهر؟ r- ما التعديل المقتر ح لنموذج تقييم إختبار ات القبول الرياضية بكلية التربية الرياضية بنـين بالِين بالأزهر مان النعدي

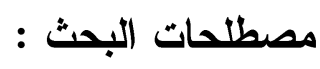
- التقييم:

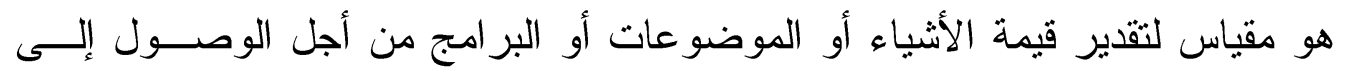

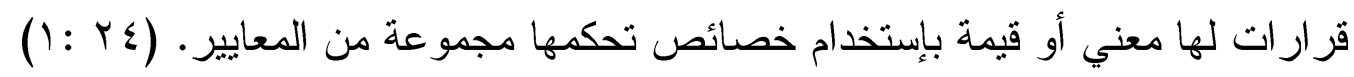
مجلة أسيوط لعلوم وفنون التربية الرياضية 
- إختبارات القبول:

هي نوع من أنواع الإختبار المهني الذي يستهدف إنتقاء أصلح العناصر للار اسة بهذه

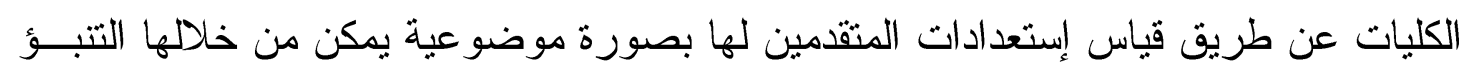

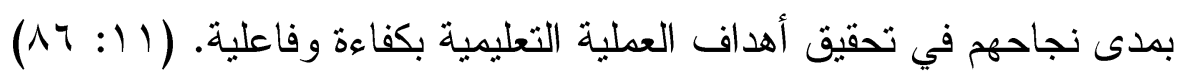
- التحليل الكيفي: هو الملاحظة المنظمة المختصة بالحكم على كيفية حركة جسم الإنسان من أجل هدف

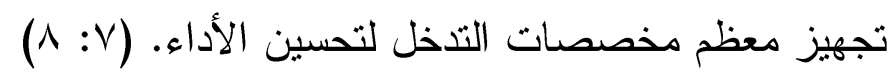
- نموذج جانجستيد (Gangstead) وبيفرياج (Beveridges):

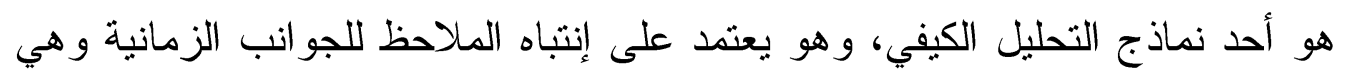

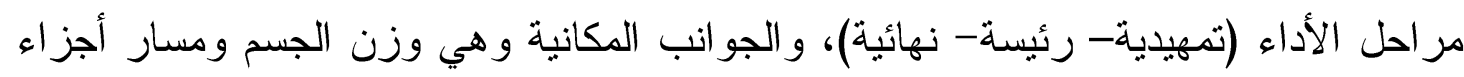

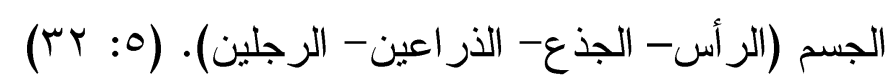
الار اسات المرتبطة: الجنات

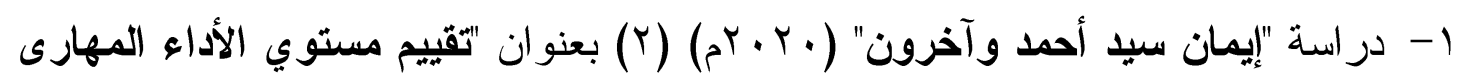

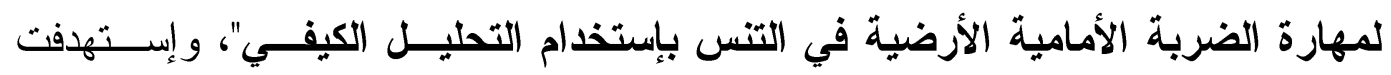

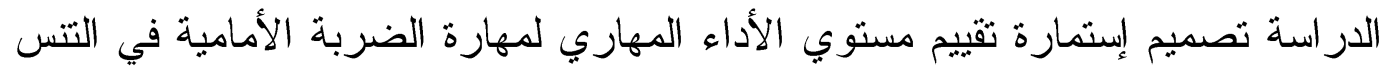

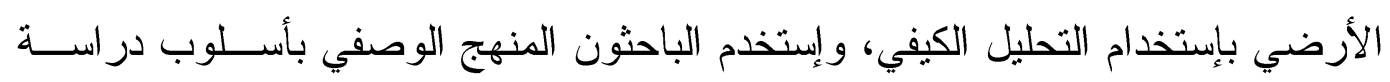

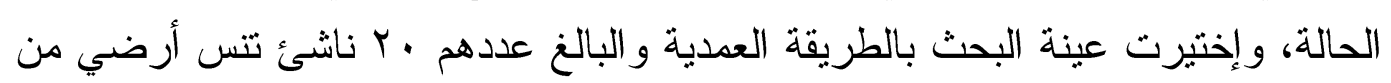

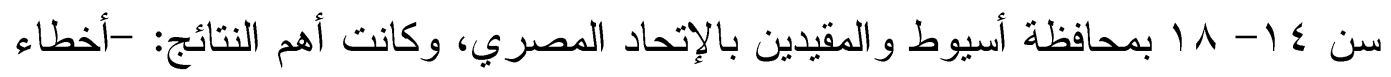

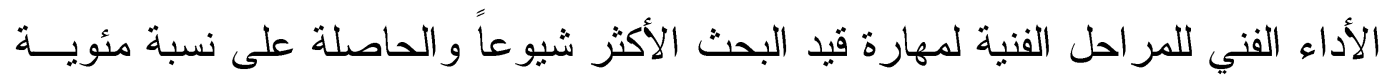

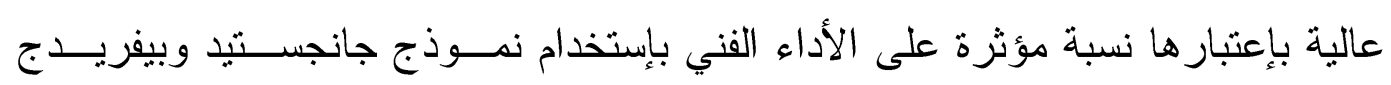

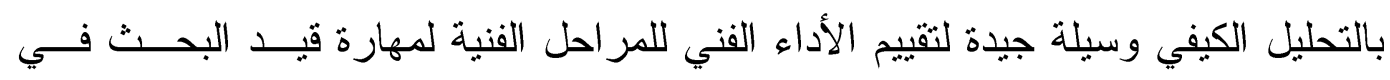

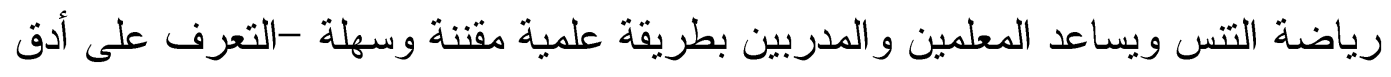

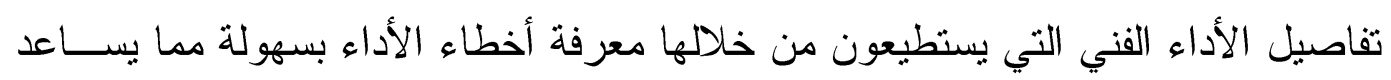

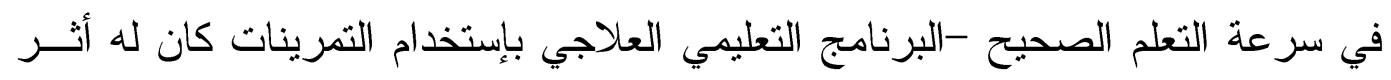

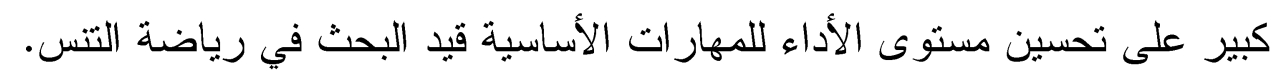

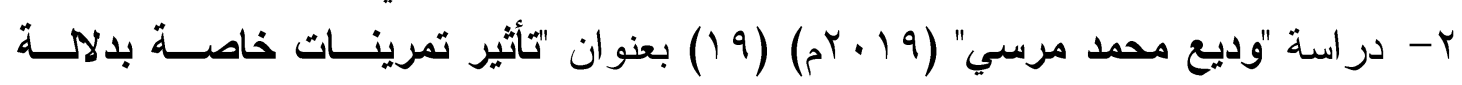

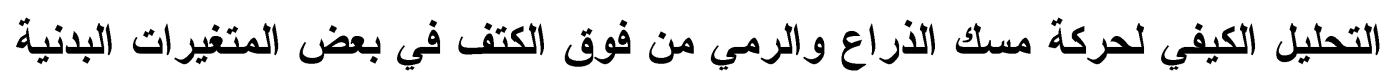

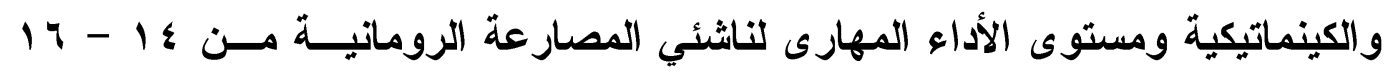

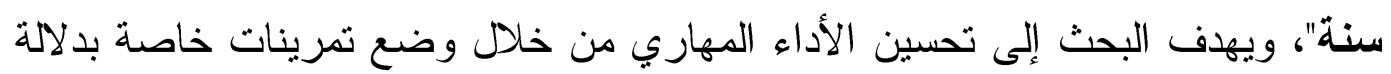


التحليل الكيفي لتطوير القدرات البدنية الخاصة للاعبي المصار عة مــن ع ا - 1 ســـنة و التعرف على تأثيرها على بعض المتغير ات البدنية و الكينماتيكية ومستوى الأداء لحركة لأنه

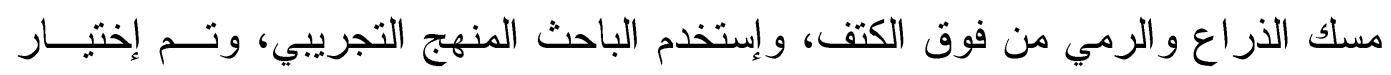

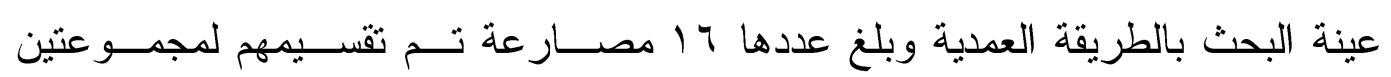

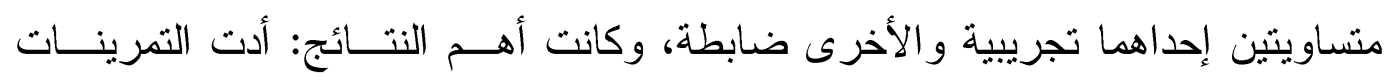
التخصصية لتحسن مستوى القوة العضلية و السرعة لدى أفر اد المجموعة التجريبية، حدث تحسن معنوي في المتغيرات الكينماتيكية (سرعة وزمن الأداء ومحصلة السرعة الخطية لمر احل الأداء) نتيجة للتمرينات الخاصة المستخدمة بالبحث -تفوقت المجموعة التجريبية

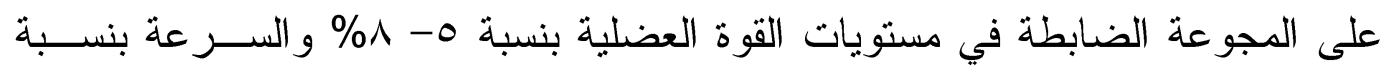

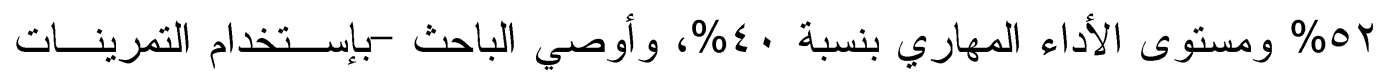

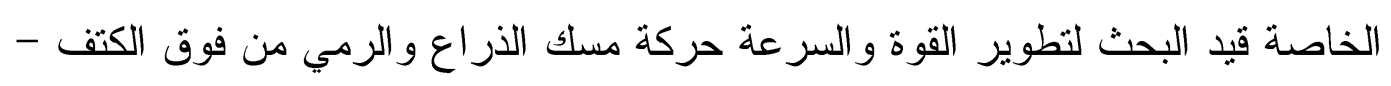

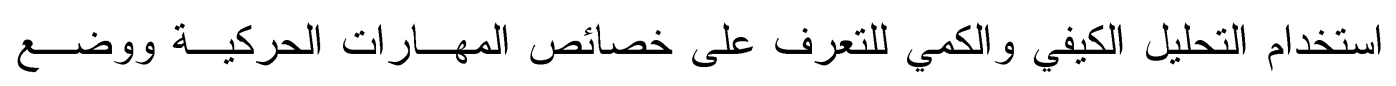
تمرينات خاصة لها وفقا لتلك الخصائص.

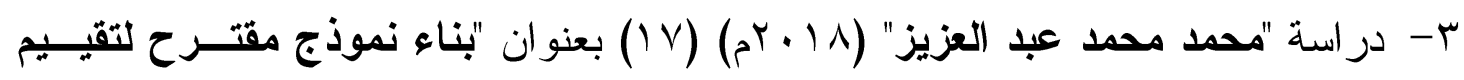

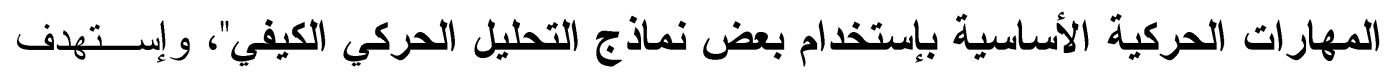

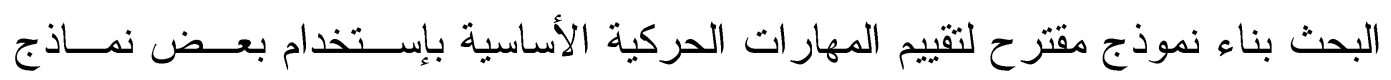

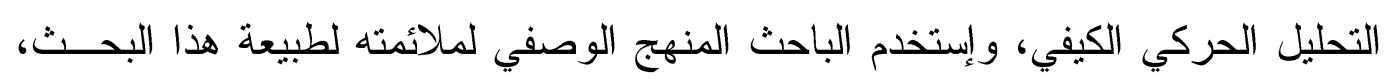
وتم إختيار عينة البحث بالطريقة العمدية من أساتذة كلية التربية الرياضية فــي الــوطن

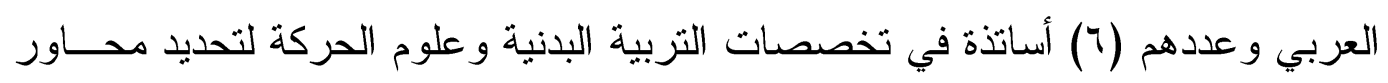

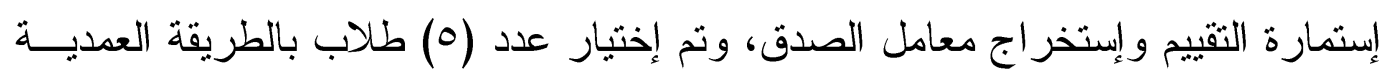

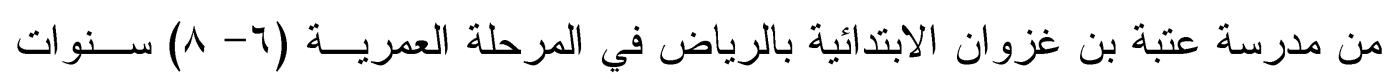
وذلك لتطبيق المهار ات الحركية الأساسية (المشي- الجري- الوثب- الرمي)، وكانت أهم

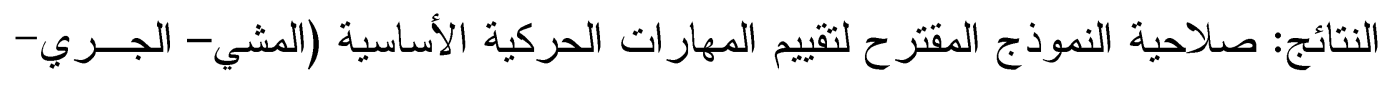

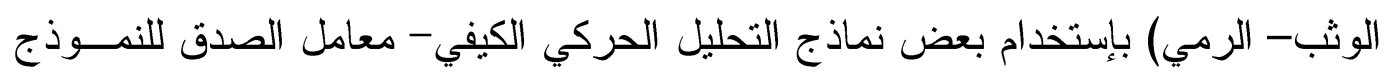

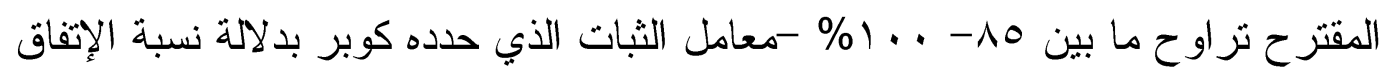

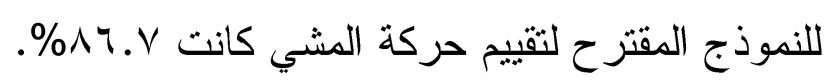
ع - دراسة "السيد على شبيب" (T ( • r) (1) بعنوان "بناء مقياس لمهارات التحليل الحركي

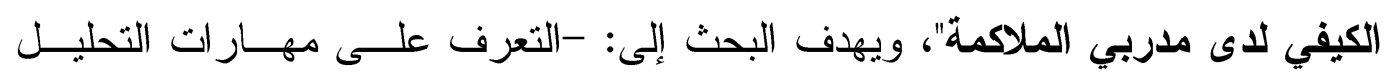
الحركي الكيفي لدي مدربي الملاكمة -بناء مقياس لمهارات التحليل الحركي الكيفي لدي مدربي الملاكمة -التعرف على مستوي مهارات التحليل الحركي الكيفي لـدي مــدربي مجلة أسيوط لعلوم وفنوز التربية الرياضية 
الملاكمة، وإستخدم الباحث المنهج الوصفي لمناسبته لطبيعة البحث، وتم إختبــار عينــة

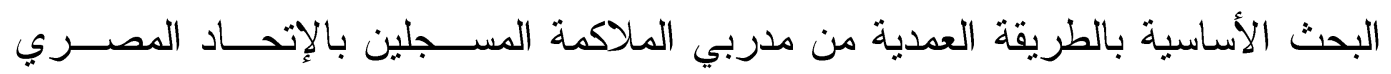

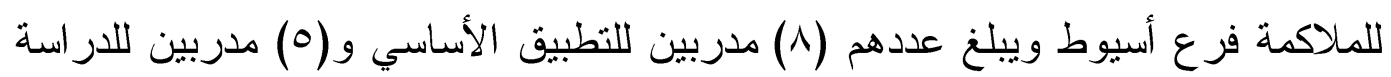

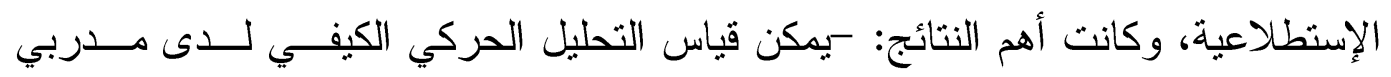

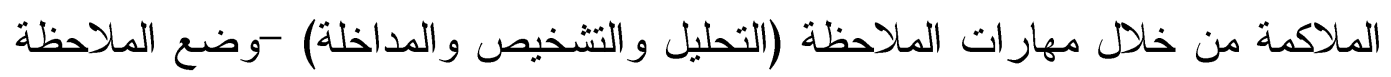

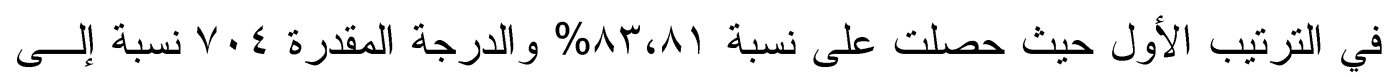

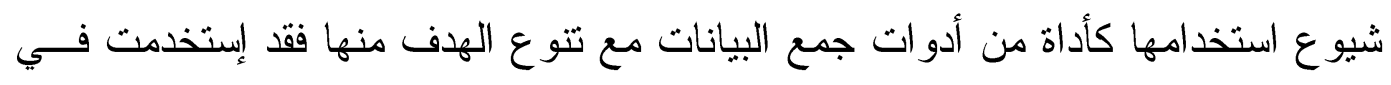

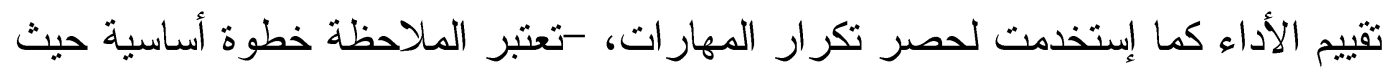

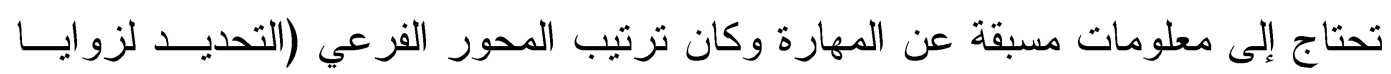

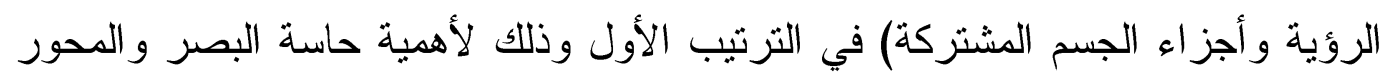

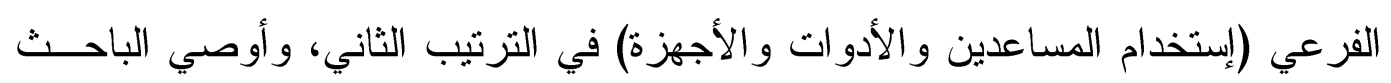

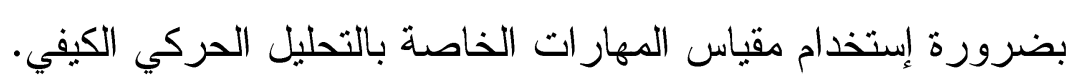

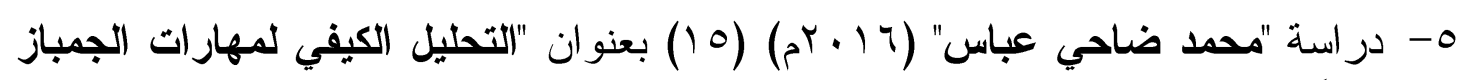

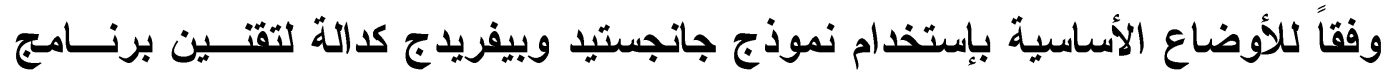

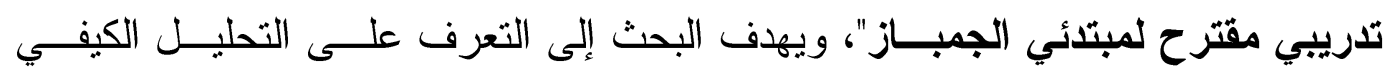

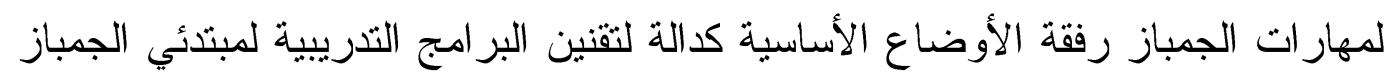

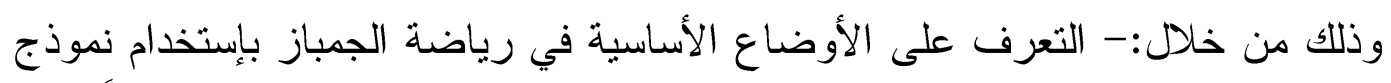

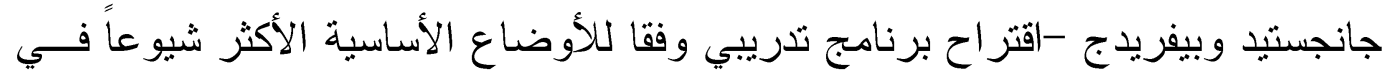

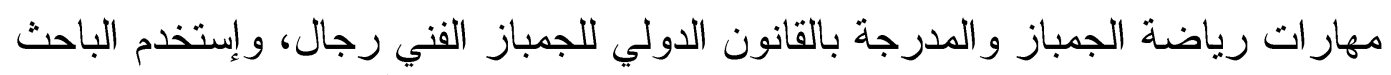

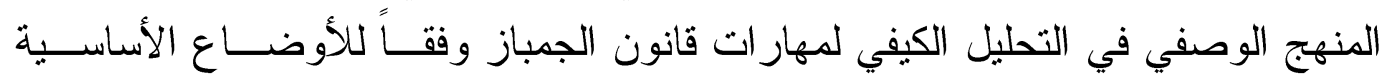

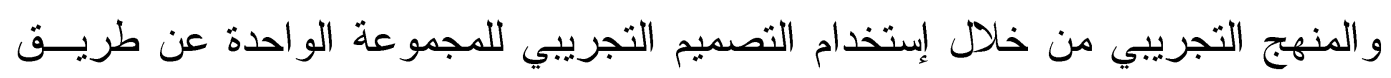

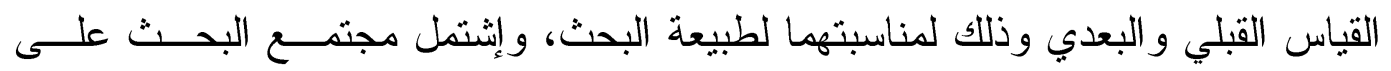

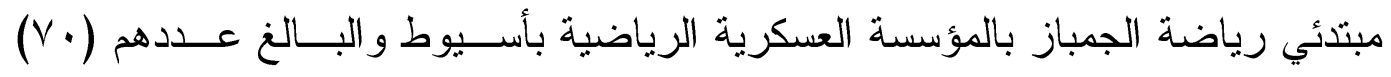

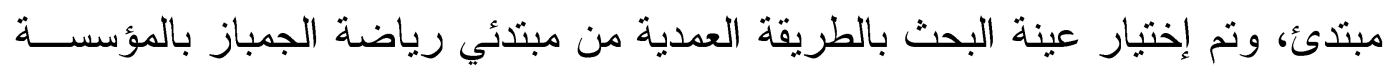

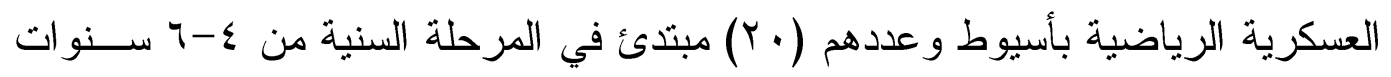

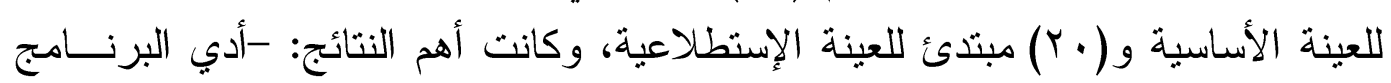

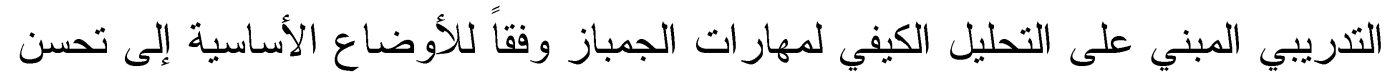

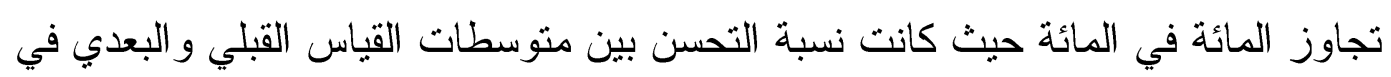

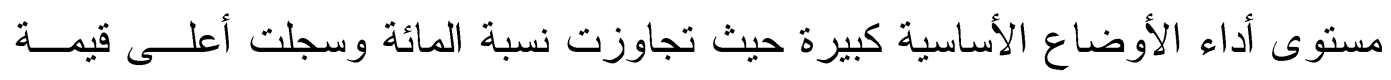


لوضع الطبق وكانت بنسبة ^\ ا \% -كانت نسبة التحسن بين متوسطات القياس القبلـ

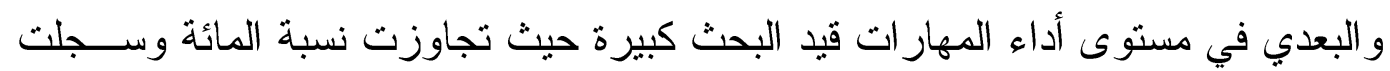

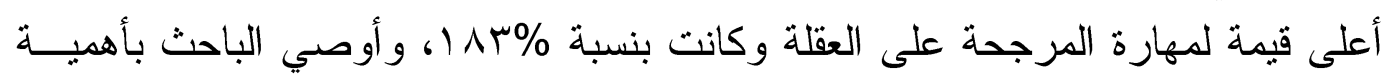

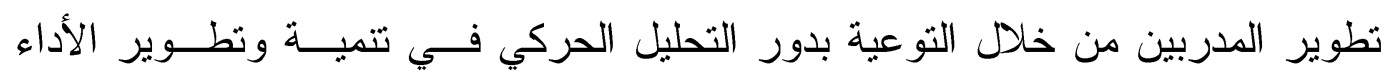
الرياضي.

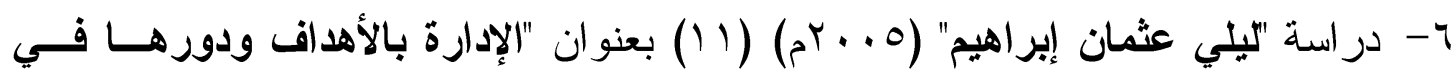
تطوير إختبارات القبول بكلية التربية الرياضية للبنين جامعة حلوان (دراسة تحليلية)"، ويهدف البحث إلى التعرف على دور الإدارة بالأهداف في تطوير إختبار ات القبول بكلية

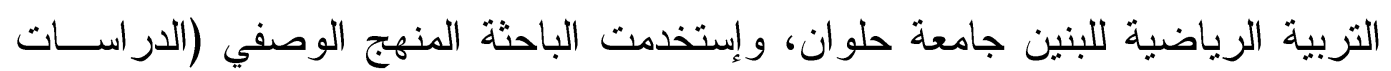

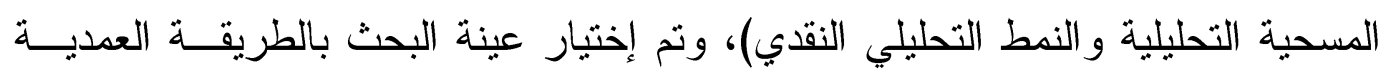

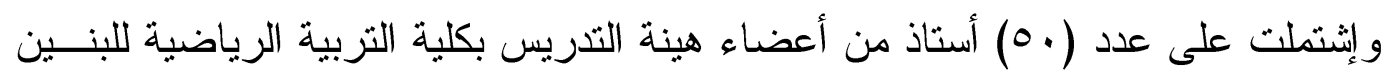

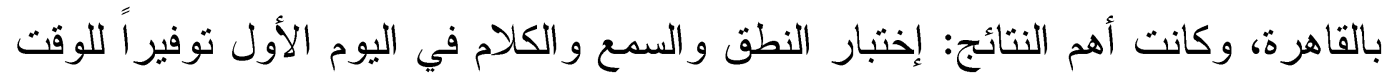

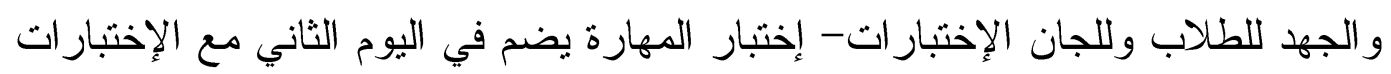
البدنية ويعطي · r درجة فقط وتضاف إلى درجات الإختبار ات الأخرى- تعديل إختبار

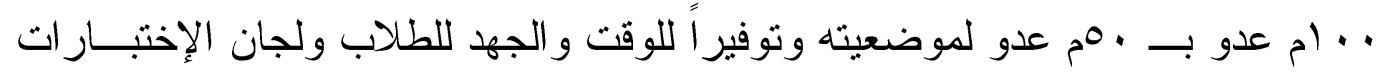

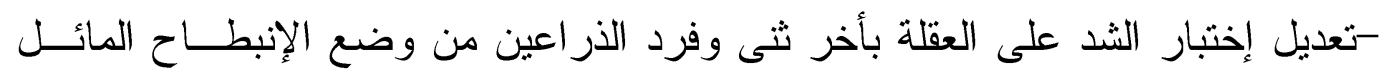
لموضعيته -تعديل إختبار الرشاقة بأخر الجري الزجز اجى لموضعيته -تعــديل إختبـار المرونة ليصبح من وضع الجلوس الطويل.

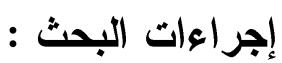
منهج البحث: إستخدام الباحث المنهج الوصفي التحليلي لمناسبته لطبيعة الدر اسة مســتخدماً بــر امج الكمبيوتر . عينة البحث: تم إختبار عينة البحث بالطريقة العددية و إثتملت علي:

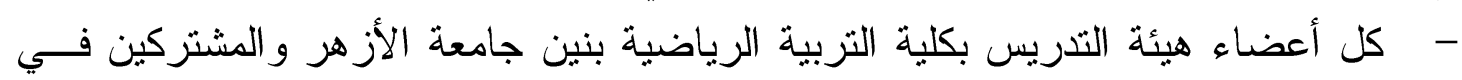

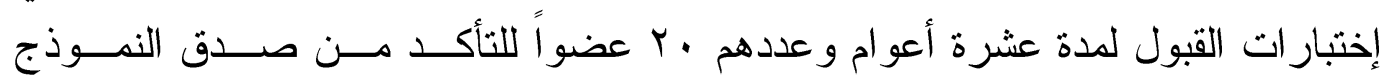
المقتر ح. - عدد • ا طلاب من الطلاب المتقدمين للقبول بكلية التربية الرياضية بنين جامعة الأزهر للتأكد من ثبات النموذج المقتر ح. 
أجهزة وأدوات جمع البيانات

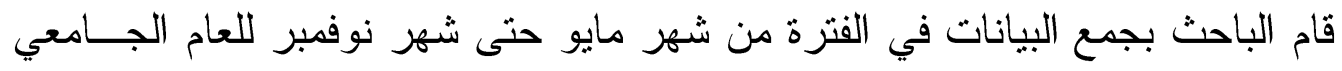

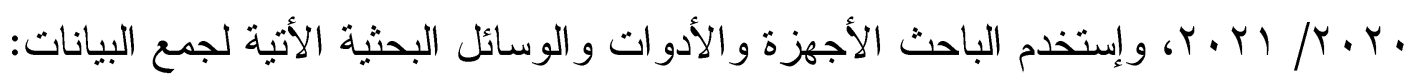

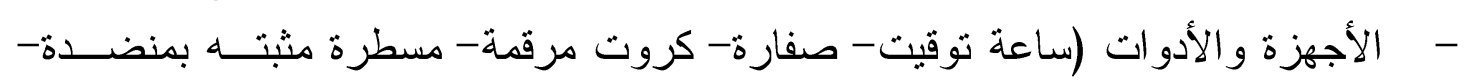

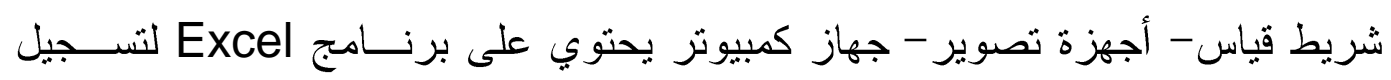

$$
\text { البيانات و إجر اء الحسابات الإحصائية). }
$$

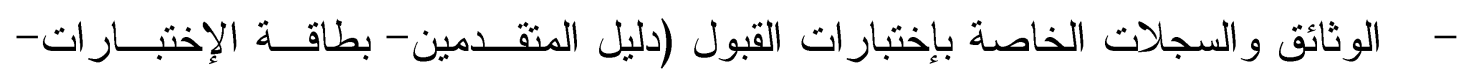
إحصائيات من وحدة الحاسب الألى بالكلية).

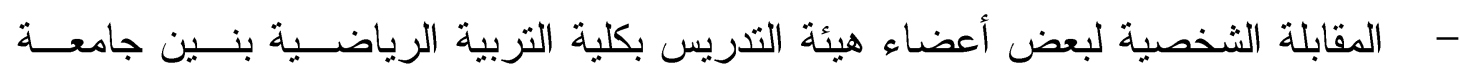

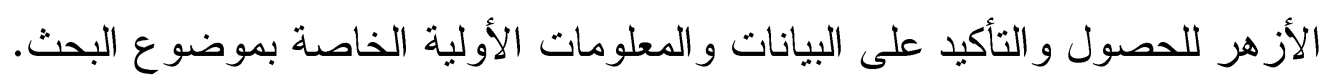

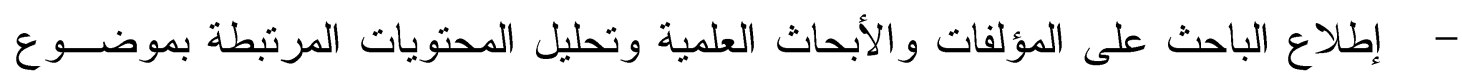

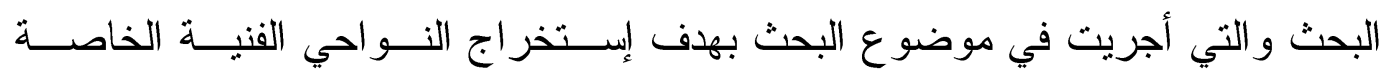
بالإختبار ات قيد البحث.

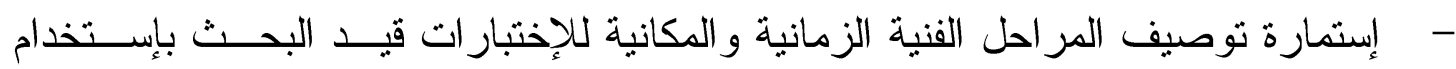
نموذج جانجستيد وبيفريدج. - - إستمارة تصنيف أهم الأخطاء الثائعة بإختبار ات القبول قيد البحث.

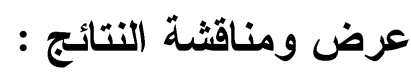

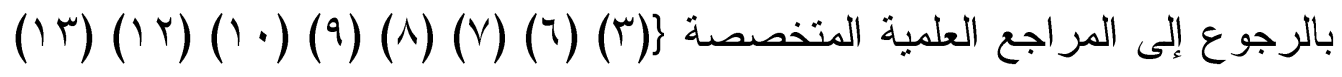

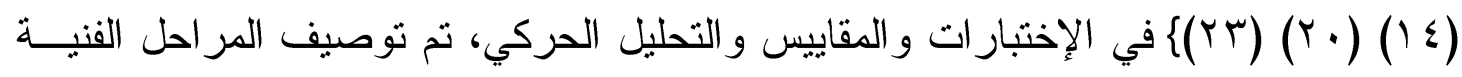

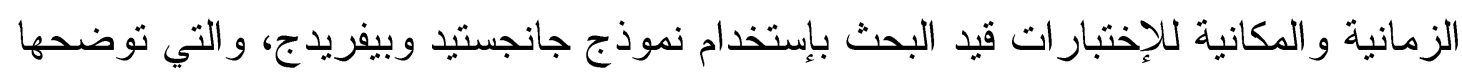

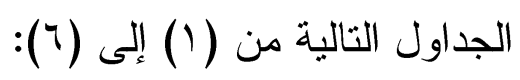

\section{جدول (1)}

توصيف المراحل الفنية الزمانية والمكانبة لاختبار السرعة عدو ، ج. ام بإستخدام نموذج

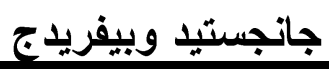

\begin{tabular}{|c|c|c|c|}
\hline \multicolumn{3}{|c|}{ المراحل الزمانية } & \multirow{2}{*}{ المكافية } \\
\hline نمائية & رئيسية & تمهيدية & \\
\hline 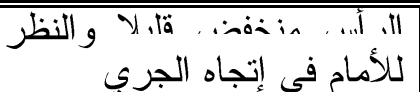 & 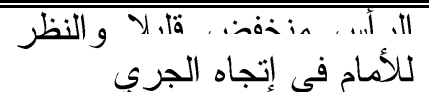 & 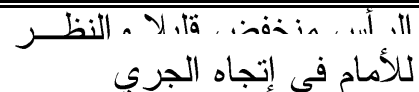 & الر أس \\
\hline 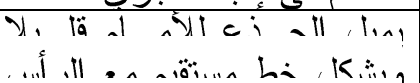 & 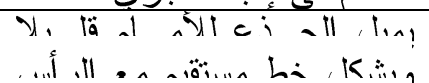 & 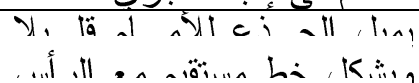 & \\
\hline 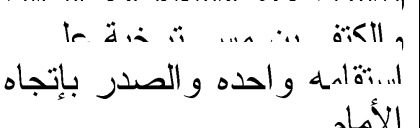 & 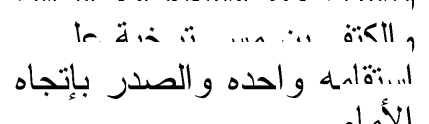 & 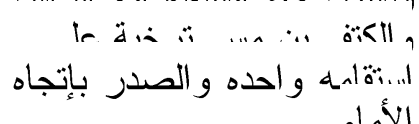 & الجذع \\
\hline ة الري & مجالة أسيوطالع & & \\
\hline
\end{tabular}




\section{تابع جدول (1) (1)}

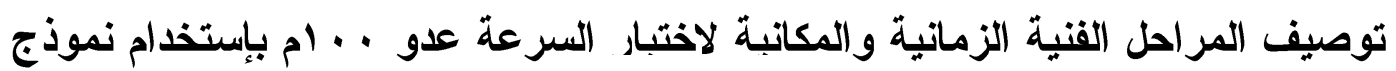

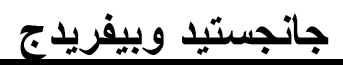

\begin{tabular}{|c|c|c|c|}
\hline \multicolumn{3}{|c|}{ المراحل الزمانية } & \multirow{2}{*}{ المكانية. } \\
\hline نـمائية & رئيس11ية & تمهبيدية & \\
\hline 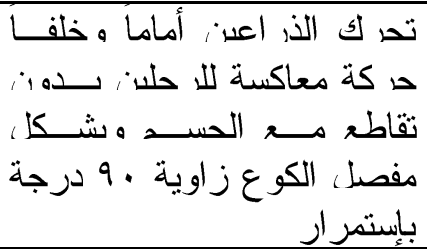 & 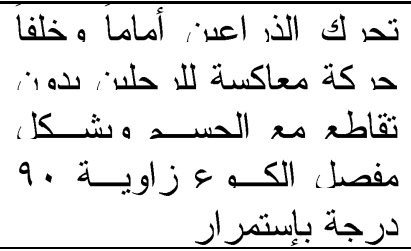 & 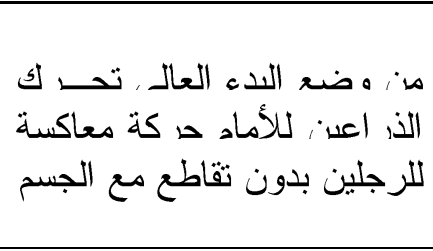 & الذر اعين \\
\hline 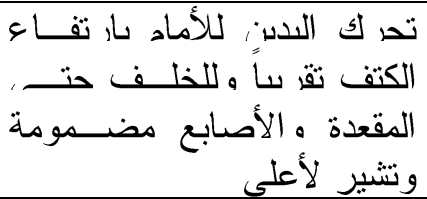 & 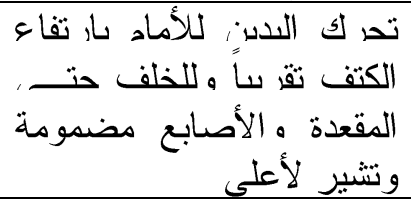 & تصدومة الندان; للأماد ه الأصسابع & اليدين \\
\hline 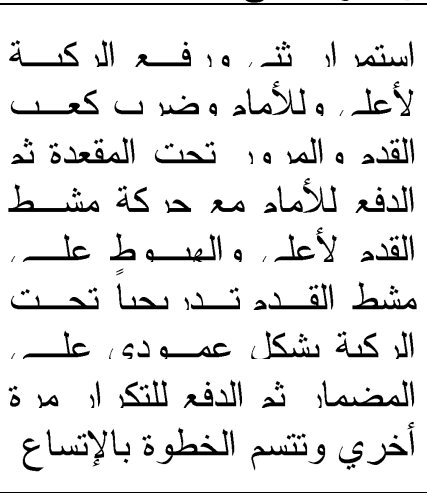 & 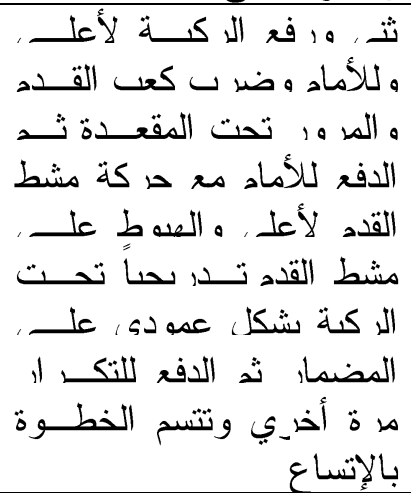 & 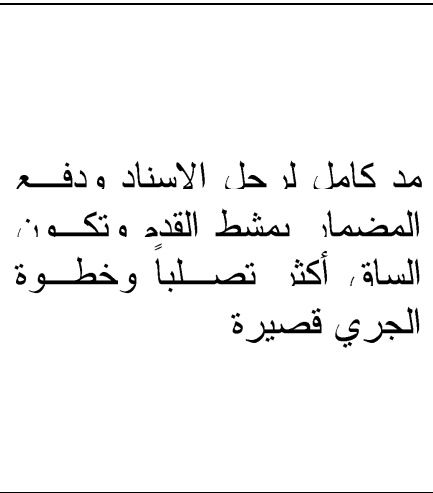 & الرجلين \\
\hline 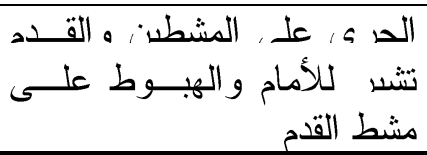 & 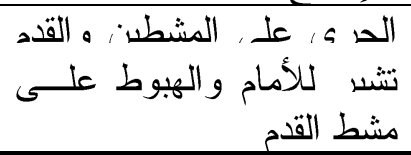 & الأرضاه القدمان, للأمـــام ودفــع القدم & القدمين \\
\hline
\end{tabular}

\section{جدو (r) (r)}

توصيف المراحل القنبة الز مانبة و المكانبة لاختبار تحمل القوة (الانبطاح المائل ثني الأر اعين) بإستخدام نموذج جانه ولانه لانبتيد وبيفريدج

\begin{tabular}{|c|c|c|c|}
\hline \multicolumn{3}{|c|}{ المراحل الزمانية } & \multirow{2}{*}{ المكانبية } \\
\hline نـهائية & رئيسيةية & تمهيدية & \\
\hline 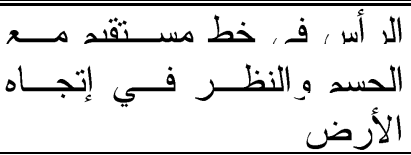 & 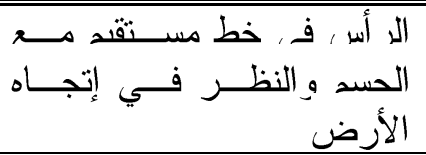 & 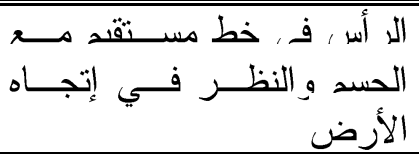 & الر أس \\
\hline 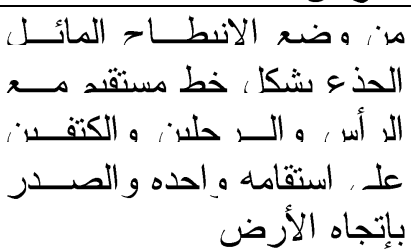 & 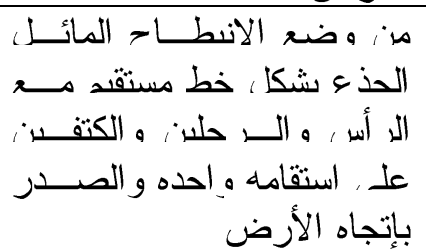 & 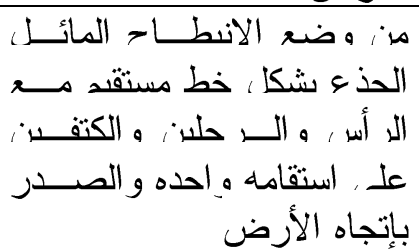 & الجذع \\
\hline
\end{tabular}




\section{تابع جدول (r)}

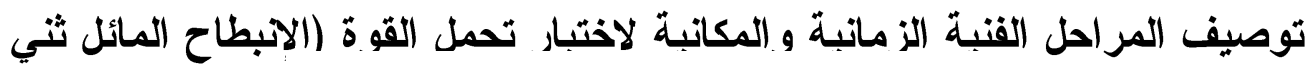
الأر اعين) بإستخدام نموذج جانجستيد وبيفريدج

\begin{tabular}{|c|c|c|c|}
\hline \multicolumn{3}{|c|}{ المراحل الزمانبية } & \multirow{2}{*}{ المكانبية } \\
\hline نـمائية & رئبيسةبة & تمهميدية & \\
\hline 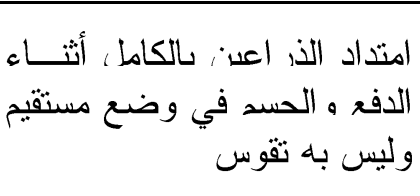 & 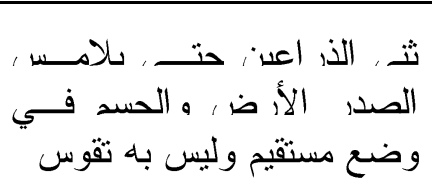 & 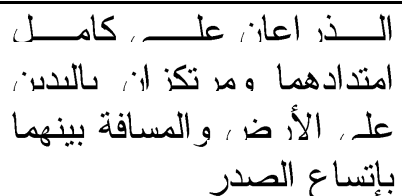 & الذر اعين \\
\hline 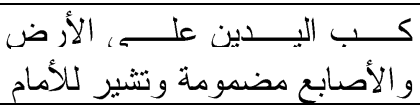 & 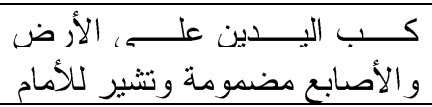 & كب اليدين على الأرض و الأصابع & البدين \\
\hline 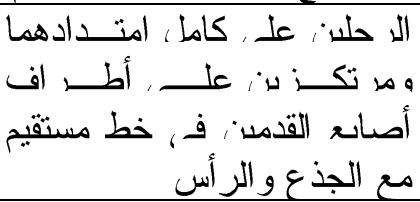 & 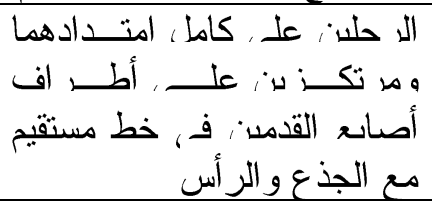 & 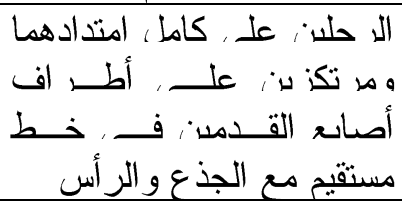 & الرجلين \\
\hline 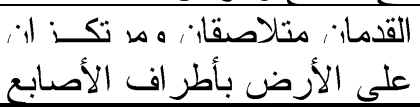 & 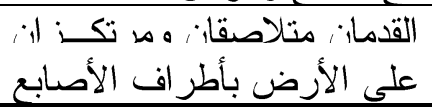 & 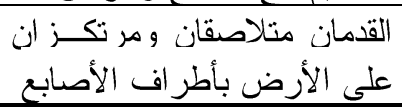 & القدمين \\
\hline
\end{tabular}

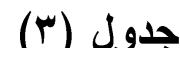

توصيف المر احل الفنية الزمانية و المكانية لاختبار. القدرة (الو ثب العريض من الثبات)

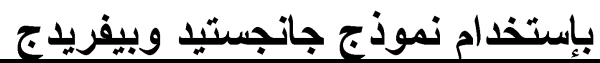

\begin{tabular}{|c|c|c|c|}
\hline \multicolumn{3}{|c|}{ المراحل الزمانبية } & \multirow{2}{*}{ المكانية الملة } \\
\hline نـمائية & رئيسلية & تمهميدية & \\
\hline |لطبيعى الـ قبة للعـودة لوضــعها & سلجس الرقبة خلفا لتكمل تقوس & و النظر ف في إتجاه الأمام الطبيعـي & الر أس \\
\hline 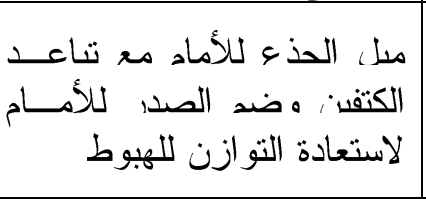 & 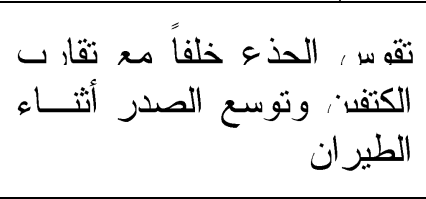 & 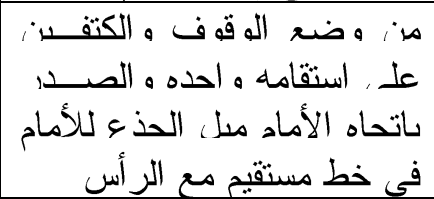 & الجذع \\
\hline 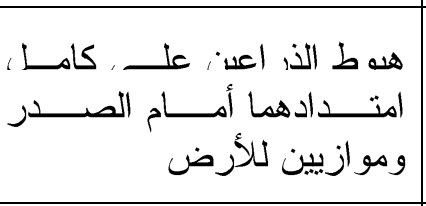 & 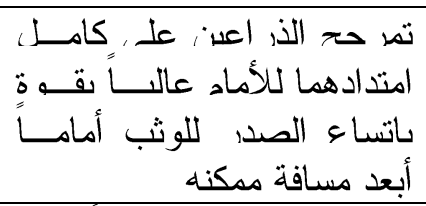 & 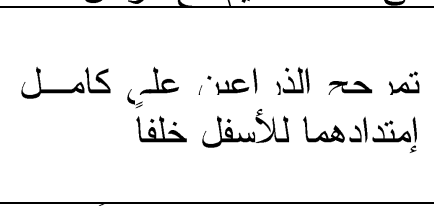 & الذر اعين \\
\hline 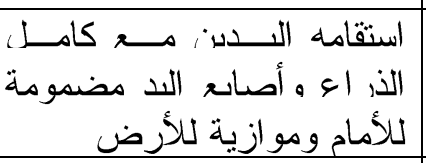 & 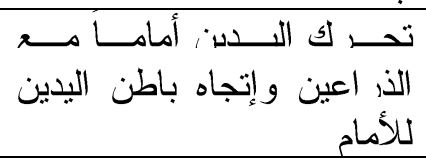 & 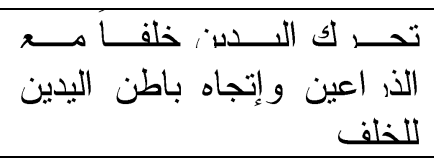 & اليدين \\
\hline 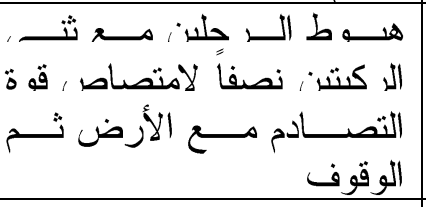 & 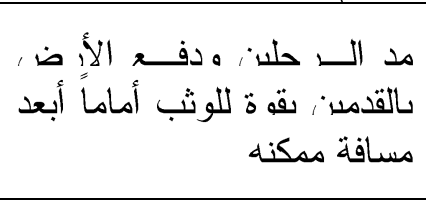 & ثني الركبتين نصفاً & الرجلين \\
\hline السقوط خلفاً القدمين وتجنــب & معاًِع بالقدمين والإرتقاء بهما & 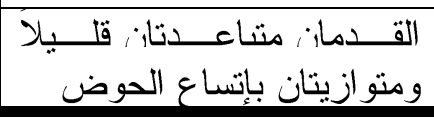 & القدمين \\
\hline
\end{tabular}




\section{جدول (ع)}

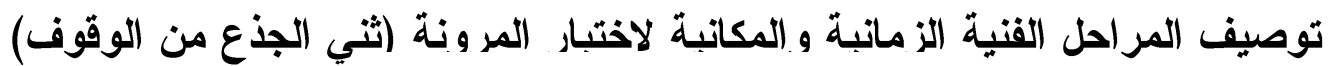

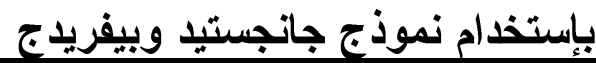

\begin{tabular}{|c|c|c|c|}
\hline \multicolumn{3}{|c|}{ المراهل الزمانية } & \multirow{2}{*}{ المكانية المرالية } \\
\hline نـهائية & رئيسيةية & تمهيدية & \\
\hline 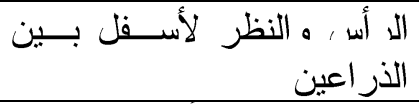 & 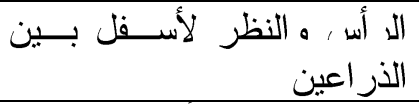 & 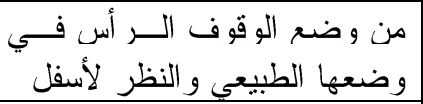 & الر أس \\
\hline ثدي ممكن و الثبات أسفل أقصي & ثدي ممكن الحذع أمامأ أسفل أقصي & ثني الجذع أماماً وللأسفل & الجذع \\
\hline 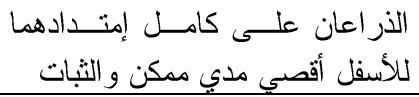 & 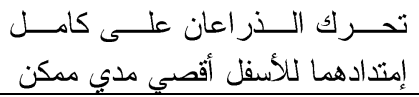 & للأسفل اعان على كامل إمتدادهما & الذر اعين \\
\hline 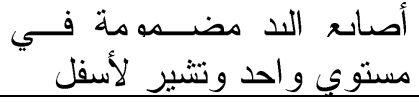 & 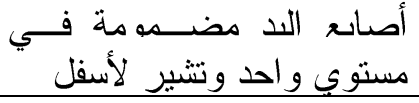 & 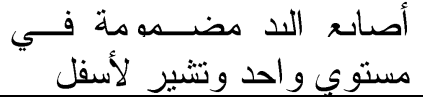 & اليدين \\
\hline 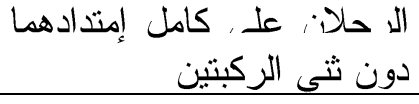 & دالا حلاً، , علـ, كامل إمتدادهما & 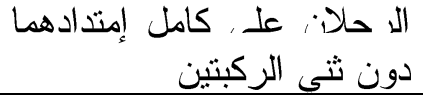 & الرجلين \\
\hline 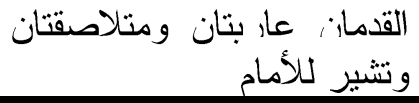 & 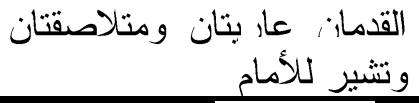 & والقيرمار، عأر بتان ومتلاصقتان & القدمين \\
\hline
\end{tabular}

$$
\text { جدوال (0) }
$$

توصيف المراحل القنية الز مانبة و المكانبة لاختبار الرشاقة (الانبطاح المائل من الوقوف)

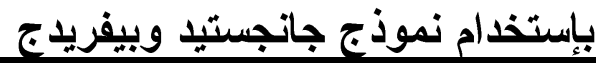

\begin{tabular}{|c|c|c|c|}
\hline \multicolumn{3}{|c|}{ الهراحل الزمانية } & \multirow{2}{*}{ المكانية } \\
\hline نـهائية & رئيسية & تمهبيدية & \\
\hline وضع الأسوف , لأعلى وصولاً إلى & 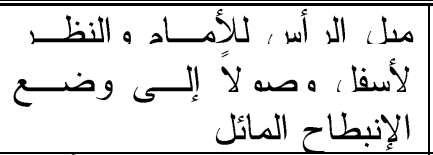 & 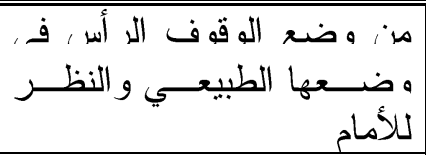 & الر أس \\
\hline وضع الوقذوف لأعلى وصولا إلى & 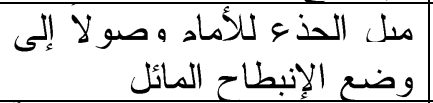 & 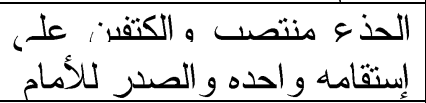 & الجذع \\
\hline 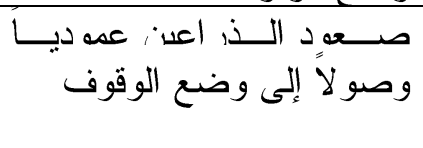 & 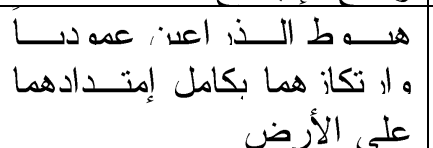 & بجوار الجسم الذع كامل إمتدادهما & الذر اعين \\
\hline 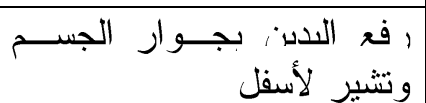 & 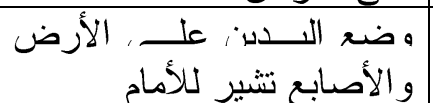 & لأسفلان, بجوار الجسم ونتـــير & اليدين \\
\hline 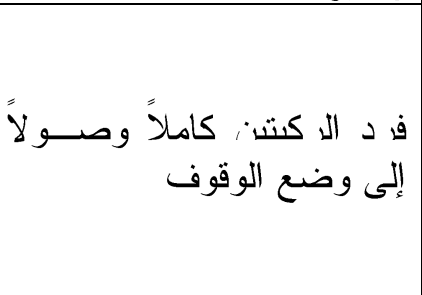 & 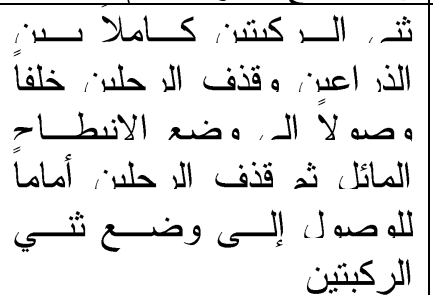 & إمتدادهما الرِجلين على كامـلـل & الرجلين \\
\hline 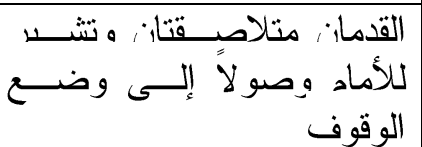 & 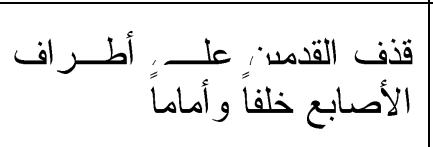 & 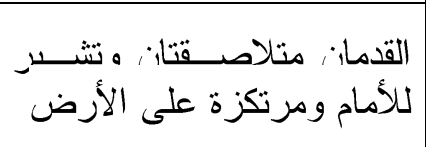 & القدمين \\
\hline
\end{tabular}




\section{1}

جدول (7)

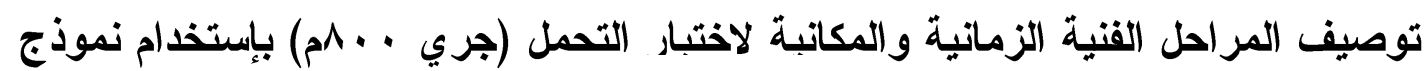
جانجستيد وبيفريدج لاختيار

\begin{tabular}{|c|c|c|c|}
\hline \multicolumn{3}{|c|}{ المراحل الزمانبة } & \multirow{2}{*}{ المكانية } \\
\hline نـهائية & رئيسبة & تمهبيدية & \\
\hline الجرئ , و النظر للأمام في إتجاه & الجرى , و النظر للأمام في إتجاه & الجرى ، و النظر للأمام في إتجاه & الر أس \\
\hline 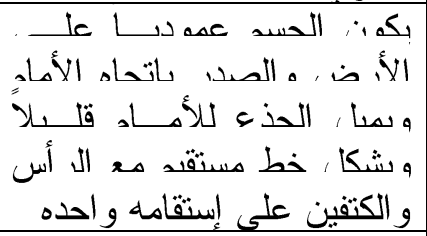 & 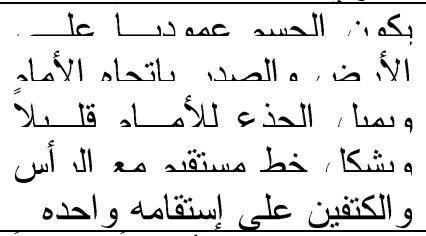 & 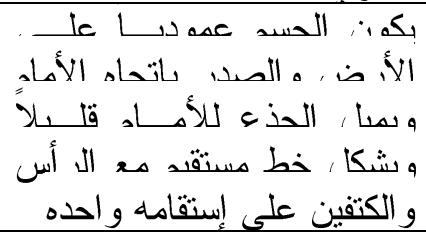 & الجذع \\
\hline 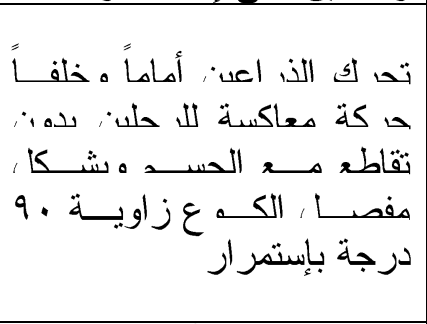 & 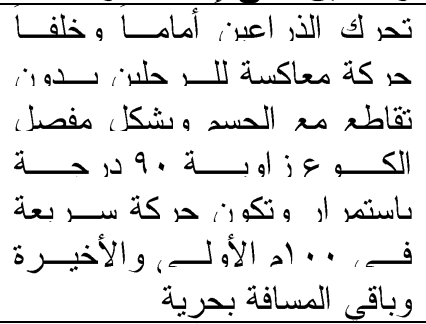 & 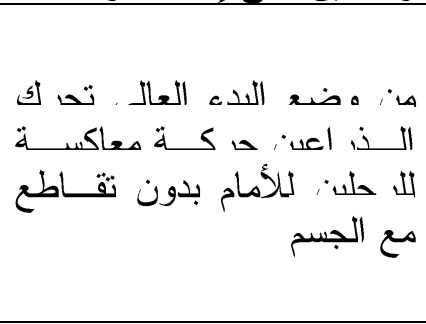 & الذر اعين \\
\hline 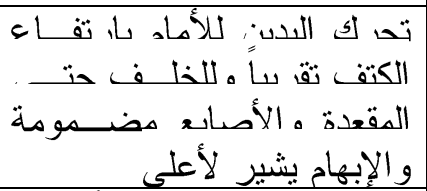 & 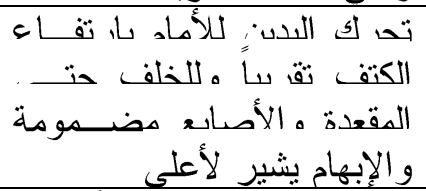 & 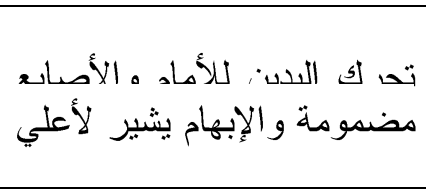 & اليدين \\
\hline 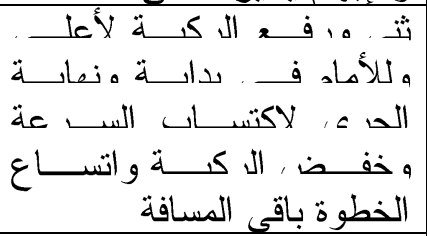 & 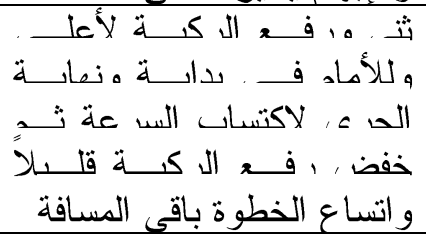 & 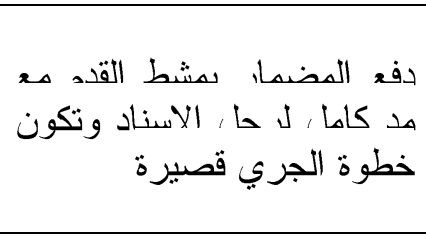 & الرجلين \\
\hline 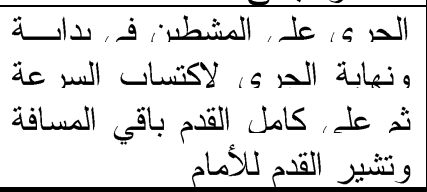 & 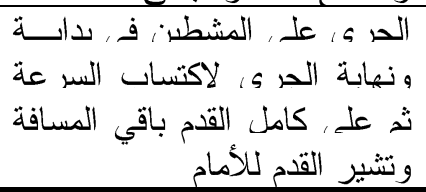 & 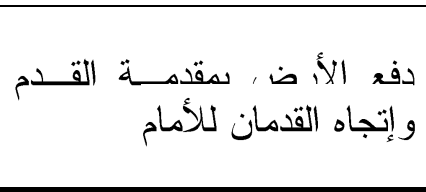 & القدمين \\
\hline
\end{tabular}

ومن خلال ما تم عرضه سابقاً بالجداول من (1 - 7) تمت الإجابة علـى التسـاؤل

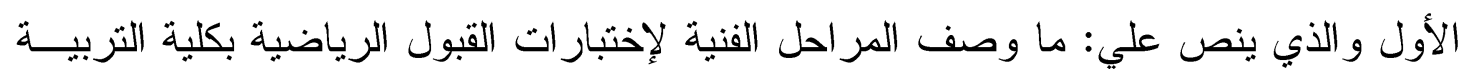

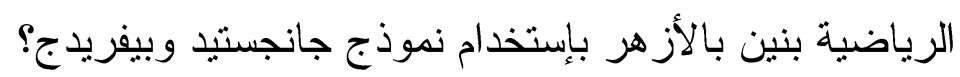

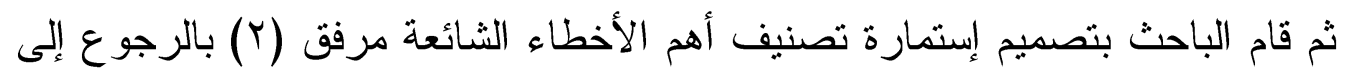

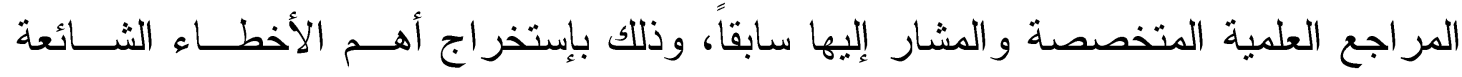

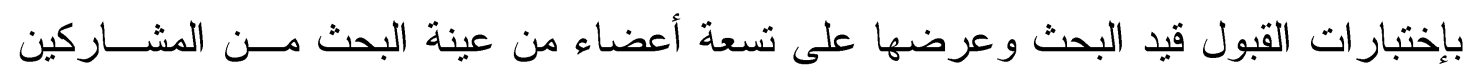

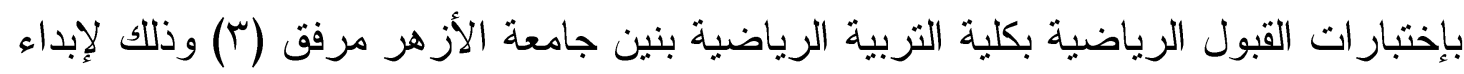
أر اءهم و التي توضحها الجداول التالية من (V) إلى (r آ): - 


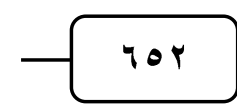

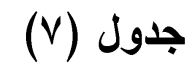

تصنيف الأخطاء الثائعة لإختبار السرعة (عدو . . ام) ن=9

\begin{tabular}{|c|c|c|c|c|c|c|}
\hline \multirow{2}{*}{ 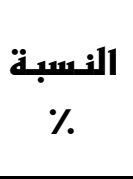 } & \multirow{2}{*}{ 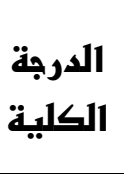 } & \multicolumn{3}{|c|}{ دروة الفطاً } & \multirow[b]{2}{*}{ الأفطاء الشائعة } & \multirow[b]{2}{*}{ م } \\
\hline & & كبير & $\begin{array}{l}\text { متوسط } \\
\text { (H) }\end{array}$ & (1) & & \\
\hline$\varepsilon \varepsilon$ & ir & - & $r$ & 7 & الإنطلاق قبل سماع أمر البدء & 1 \\
\hline «1 & 11 & - & r & $\mathrm{v}$ & عدم النظر للأمام في إتجاه الجري & r \\
\hline$v \varepsilon$ & r. & $r$ & 0 & 1 & عدم مبل الجذع للأمام قليلاً و إستقامته مع الر أس & r \\
\hline 19 & $r \varepsilon$ & 7 & r & - & الكتف مشدودة دون إسترخاء & $\varepsilon$ \\
\hline $9 \pi$ & ro & $\mathrm{v}$ & r & - & 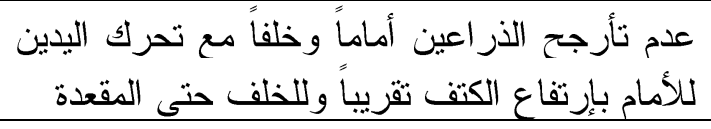 & 。 \\
\hline$V \varepsilon$ & r. & $\varepsilon$ & r & $r$ & تقاطع الذر اعين مع الجسم ل & 1 \\
\hline or & $1 \varepsilon$ & 1 & r & 0 & إتجاه القدمان في إتجاه مخالف للأكمام & $\mathrm{v}$ \\
\hline 10 & r & 1 & r & 1 & توقف ثني ورفع الركبة لأعلى وللأمام & $\wedge$ \\
\hline 94 & ro & 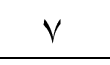 & $r$ & - & لم يتم الدد الكامل لرجل الإسناد الخلفية & 9 \\
\hline 94 & ro & $\mathrm{v}$ & $r$ & - & عدم دفع الأرض بمشط القدم ع & 1. \\
\hline 19 & $r \varepsilon$ & 1 & r & - & عدم الجرب في الحارة المخصصة للمنسابق & 11 \\
\hline
\end{tabular}

جلول (^)

تصنيف الأخطاء الثنائعة لإختبار تحمل القوة (الإبطاح المائل ثني الأراعين) ن=و

\begin{tabular}{|c|c|c|c|c|c|c|}
\hline \multirow{2}{*}{ 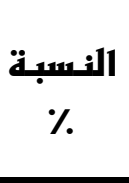 } & \multirow{2}{*}{ الكلية } & \multicolumn{3}{|c|}{ درجة الفطأ } & \multirow[b]{2}{*}{ الأفطاء الشائعة } & \multirow[b]{2}{*}{ م } \\
\hline & & كبير & $\begin{array}{c}\text { متوسط } \\
\text { (I) }\end{array}$ & (1) & & \\
\hline$\varepsilon \wedge$ & w & 1 & r & 1 & عدم النظر للأسفل في إتجاه الأرض & 1 \\
\hline 10 & r & 1 & r & 1 & 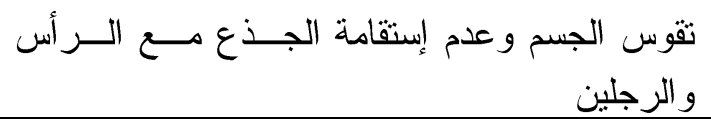 & r \\
\hline$\varepsilon \varepsilon$ & ir & - & r & 1 & الصدر في غير إتجاه الأرض ال & r \\
\hline$\varepsilon$ & 11 & - & $r$ & $\mathrm{v}$ & الكتفان لبس على إستقامه و احده & $\varepsilon$ \\
\hline 19 & $r \varepsilon$ & 1 & r & & الدسافة بين الذراعين ليست بإتساع الصدر & 0 \\
\hline 19 & $r \varepsilon$ & $\mathrm{v}$ & 1 & 1 & عدم إمتداد الذر اعين بالكامل أثناء الدفع ع & 7 \\
\hline 97 & r & $\wedge$ & 1 & - & أثناء الهبوطى الذراعين حتى يلامسس الصــدر الأرض & $\mathrm{v}$ \\
\hline Tr & iv & r & $\varepsilon$ & r & ثني الركبنتين & $\wedge$ \\
\hline 10 & r & 7 & $r$ & 1 & تباعد القدمين & 9 \\
\hline 07 & 10 & $r$ & $r$ & 0 & عدم إرتكاز القدم على الأرض بأطر اف الأصابع & 1. \\
\hline \multicolumn{5}{|c|}{ مجلة أسيوط لعلوم وفنون التربية الرياضية } & & \\
\hline
\end{tabular}




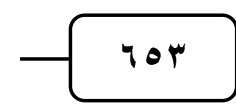

جدول (9)

تصنيف الأخطاء الثائعة لإختبار القدرة (الوثب العريض من الثبات) ن=و

\begin{tabular}{|c|c|c|c|c|c|c|}
\hline \multirow{2}{*}{ 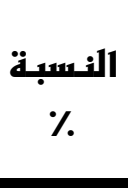 } & \multirow{2}{*}{ ال الكرجة } & \multicolumn{3}{|c|}{ درجة الفطاً } & \multirow[b]{2}{*}{ الأفطاء الشائعة } & \multirow[b]{2}{*}{ م } \\
\hline & & كبير & $\begin{array}{l}\text { متوسط } \\
\text { (r) }\end{array}$ & بسيط & & \\
\hline 10 & r & 1 & r & 1 & 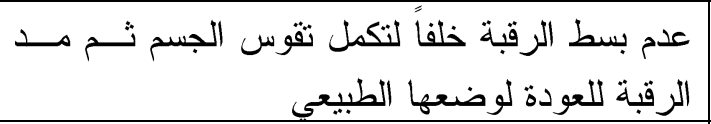 & 1 \\
\hline 97 & r & $\wedge$ & 1 & - & عدم تقارب الكتفين وتوسع الصدر أثناء الطير ان & r \\
\hline qr & ro & $\mathrm{v}$ & r & - & عدم تقوس الجذع خلفاً أثناء الطيران & r \\
\hline 10 & r & 1 & r & 1 & عدم ميل الجذع للأمام أثناء الهبوط & $\varepsilon$ \\
\hline 10 & r & 1 & $r$ & 1 & عدم تباعد الكتفين وضم الصدر للأمام أثناء الهيوط & 0 \\
\hline$v \varepsilon$ & $r$. & $\varepsilon$ & r & r & عدم ترج جح الذراعبن أماماً وخلفاً على كامل إمتدادهما عالياً & 7 \\
\hline$v \varepsilon$ & r. & $\varepsilon$ & r & r & عدم دفع الأرض بالقدمين بقوة أثناء الطيران & $\mathrm{v}$ \\
\hline$V \varepsilon$ & $r$. & $r$ & 0 & 1 & عدم مد الرجلين أثناء الوثب للطير ان & $\Lambda$ \\
\hline$v \varepsilon$ & $r$. & $\varepsilon$ & r & r & عدم ثني الركبتين نصفاً أثثناء الهبوط & 9 \\
\hline TV & 11 & r & r & r & القدمان غير متباعدتين ومتو ازيتين بإنساع الحوض & 1. \\
\hline
\end{tabular}

جدول (·) (1)

تصنيف الأخطاء الثائعة لإختبار المرونة (ثني الجذع من الوقوف) ن=9

\begin{tabular}{|c|c|c|c|c|c|c|}
\hline \multirow{2}{*}{ النسبة } & \multirow{2}{*}{ الكالية } & \multicolumn{3}{|c|}{ درجة الفطأ } & \multirow[b]{2}{*}{ الأفطاء الشائعة } & \multirow[b]{2}{*}{ م } \\
\hline & & كبير & $\begin{array}{c}\text { متوسط } \\
\text { (H) }\end{array}$ & بسيط & & \\
\hline 10 & سז & 1 & r & 1 & عدم النظر لأسفل بين الذراعين & 1 \\
\hline qr & ro & $\mathrm{v}$ & r & - & عدم ثثى الجذع أقصى مدى ممكن أماماً للأسفل & r \\
\hline 19 & $r \varepsilon$ & $\mathrm{v}$ & 1 & 1 & عدم ثبات الجذع عند أقصى مدي ممكن من الثثى & r \\
\hline 94 & ro & $\mathrm{v}$ & r & - & الذراعان ليس على كامل إمتدادهما للأسفل أتصي مدي ممكن & $\varepsilon$ \\
\hline ᄉ) & rt & . & r & 1 & أصابع اليد غير مضمومة ولا تتشير لأسفل & - \\
\hline 19 & $r \varepsilon$ & $\mathrm{v}$ & 1 & 1 & ثنى الركبتين & 1 \\
\hline or & $1 \varepsilon$ & 1 & r & . & القدم ليست عارية & $\mathrm{v}$ \\
\hline $\mathrm{VA}$ & (I) & $\varepsilon$ & $\varepsilon$ & 1 & القدمان غير متلاصقتان و لا تشير للأمام & $\wedge$ \\
\hline
\end{tabular}




\begin{tabular}{|c|c|c|c|c|c|c|}
\hline \multicolumn{7}{|c|}{ - } \\
\hline \multirow[b]{2}{*}{ النسبة } & \multirow[b]{2}{*}{ الكالية } & \multicolumn{3}{|c|}{ درجة الخطاًاً } & \multirow[b]{2}{*}{ الأفمطاء الشُأُعة } & \multirow[b]{2}{*}{ م } \\
\hline & & كبير & $\begin{array}{c}\text { oتوس } \\
\text { (I) }\end{array}$ & باسط & & \\
\hline 09 & 17 & $r$ & r & $\varepsilon$ & عدم النظر لأمام & 1 \\
\hline$\vee \wedge$ & r) & $\varepsilon$ & $\varepsilon$ & 1 & تصلب الحذب وعدم ميله للأكام وصولا إلى وضع & r \\
\hline 09 & 17 & r & r & $\varepsilon$ & 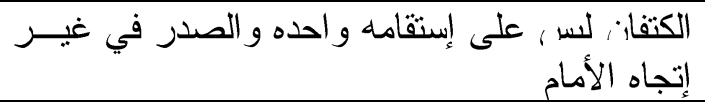 & r \\
\hline 19 & $r \varepsilon$ & 7 & r & - & الإنبطاح المتامه الجسئ مع الرأس و الرجلين في وضع & $\varepsilon$ \\
\hline 10 & $r \mu$ & 7 & $r$ & 1 & ثثى الذر اعين بجوار الجسم & 0 \\
\hline$\wedge 9$ & $r \varepsilon$ & 7 & r & - & 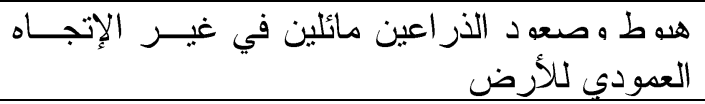 & 7 \\
\hline 19 & $r \leq$ & $\mathrm{V}$ & 1 & 1 & عدم إرتكاز الذر اعين بكامل إمتدادهما على الأرض & $\mathrm{V}$ \\
\hline 19 & $r \varepsilon$ & $\mathrm{V}$ & 1 & 1 & عدم ثنى الركبتين كاملا بين الذر اعين & $\wedge$ \\
\hline$V \leqslant$ & $r \cdot$ & $\varepsilon$ & $r$ & r & عدم إستخدام القذف خلفاُ و أماماً عند تحريك الرجلين & 9 \\
\hline $\mathrm{VA}$ & YI & $\varepsilon$ & $\varepsilon$ & 1 & عدم فرد الركبتين كاملاً وصو لا إلى وضع الوقوف & 1. \\
\hline or & $1 \leq$ & 1 & r & 0 & عدم قذف القدمين على أطر اف الأصـابع خلفاً و أماما & 11 \\
\hline$v \varepsilon$ & $r$. & r & 0 & 1 & تباعد القدمين & Ir \\
\hline
\end{tabular}

جدول (i )

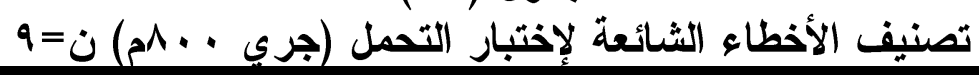

\begin{tabular}{|c|c|c|c|c|c|c|}
\hline \multirow{2}{*}{ 11 النسبة } & \multirow{2}{*}{ الكابية } & \multicolumn{3}{|c|}{ درجة الفطاًأ } & \multirow[b]{2}{*}{ الأفطاء الثائعة } & \multirow[b]{2}{*}{ م } \\
\hline & & كببر & $\begin{array}{c}\text { متوسط } \\
\text { (I) }\end{array}$ & بسيط & & \\
\hline 09 & 17 & $r$ & r & $\xi$ & الإنطلاق قبل سماع أمر البدء & 1 \\
\hline 19 & $r \leq$ & 7 & $r$ & - & عدم النظر للأمام في إتجاه الجري & $r$ \\
\hline 10 & r & 7 & r & 1 & عدم ميل الجذع للأمام قليلا و إستقامته مع الر أس & r \\
\hline 八I & rr & 0 & $r$ & 1 & الكتف مشدودة دون إسترخاء & $\varepsilon$ \\
\hline $\mathrm{V} \cdot$ & 19 & r & $\varepsilon$ & $r$ & عدم تأرجح الذر اعين أماماً وخلفاً بحر كة معاكسة للرجلين & 0 \\
\hline TV & 11 & $r$ & $\mu$ & r & تقاطع الذر اعين مع الجسم & 7 \\
\hline 19 & Ts & 7 & $r$ & - & لا بشكل مفصل الكو عز اوية ، 9 درجة بإستمرار & $\mathrm{V}$ \\
\hline 10 & rr & 7 & $r$ & 1 & خطوة الجري قصبرة بإستمر ار & $\wedge$ \\
\hline $\mathrm{VA}$ & $\begin{aligned} 1 \\
\end{aligned}$ & $\varepsilon$ & $\varepsilon$ & 1 & جري · · ام الأولى بسرعة متوسطة & 9 \\
\hline 94 & ro & $\mathrm{V}$ & $r$ & - & عدم الهجو م على خط النهاية بأقصى سرعة & 1. \\
\hline or & $1 \varepsilon$ & 1 & $r$ & 0 & إتجاه القدمان في إتجاه الجانب & 11 \\
\hline 97 & rT & $\Lambda$ & 1 & - & الدخول في الحارة الأولى فى غير الوقت المناسب & ir \\
\hline 97 & rT & $\Lambda$ & 1 & - & تجاوز المنافس من الحافة الداخلية للمضمار & M \\
\hline $7 V$ & 11 & r & $r$ & $r$ & الجري المستمر على مشط القدم & $1 \leqslant$ \\
\hline
\end{tabular}




\section{جدول (T)}

تصنيف الأخطاء الثائعة لإختبار ات القبول الرياضية ن=9

\begin{tabular}{|c|c|c|c|c|c|c|c|}
\hline \multirow{2}{*}{ النسبـة } & \multirow{2}{*}{ الكلية } & \multicolumn{3}{|c|}{ درجة الذططاً } & \multirow[b]{2}{*}{ الأَفطاء } & \multirow[b]{2}{*}{ 1إِفتنبارات } & \multirow[b]{2}{*}{ م } \\
\hline & & كببير & متوسط & بسيط & & & \\
\hline Vo & Trt & $1 \leqslant 1$ & 7. & YY & 11 & إختبار السر عة & 1 \\
\hline 79.7 & $1 \wedge \wedge$ & $11 \varepsilon$ & $\varepsilon \varepsilon$ & r. & 1. & الذراعين) تحمل القوة (الإنبطاح المائل ثتـي & r \\
\hline$\Lambda . . \vee$ & riᄉ & 104 & or & 14 & 1. & إختبار القدرة (الوثب العريض من الثبات) & $\mu$ \\
\hline$\Lambda Y . \varepsilon$ & $1 \vee \wedge$ & Irr & ب & 1. & $\Lambda$ & إختبار المرونة (ثنى الجذع من الوقوف) & $\varepsilon$ \\
\hline VT.Y & $r \leqslant V$ & 107 & $\vee \cdot$ & r) & ir & الوقوف) الرشاقة (الإنبطـــاح المائَلـل مــن & 0 \\
\hline$\vee 9.1$ & 199 & r. $\varepsilon$ & $V \varepsilon$ & rI & $1 \varepsilon$ & إختبار التحمل (جري · ·دم) & 7 \\
\hline
\end{tabular}

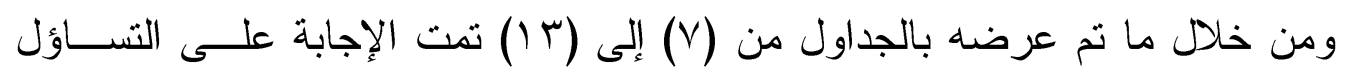

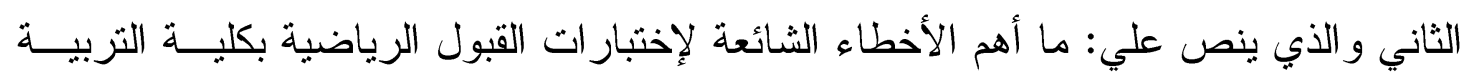

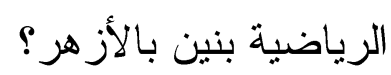

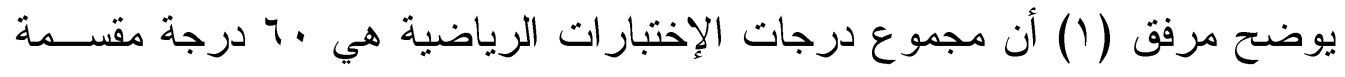

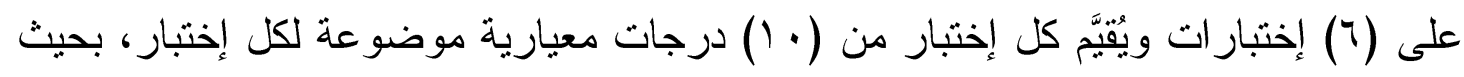

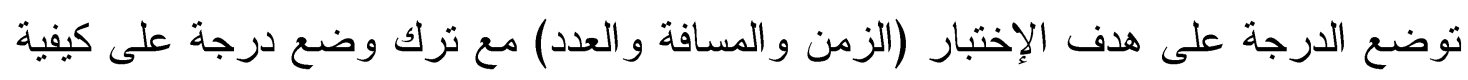

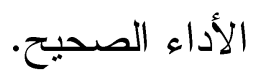

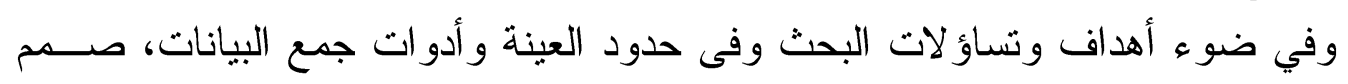

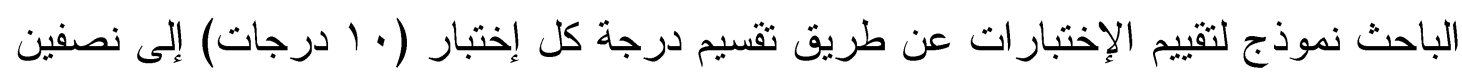

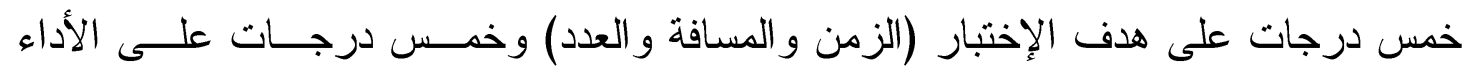
الصحيح لكل إختبار.

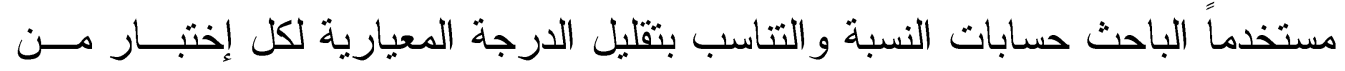

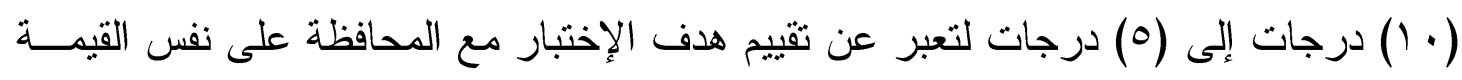

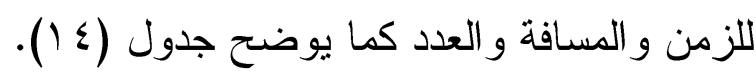

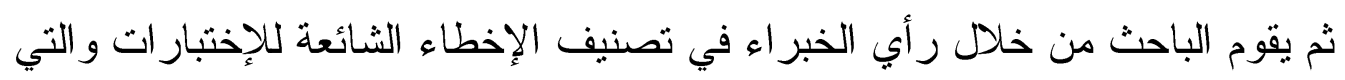

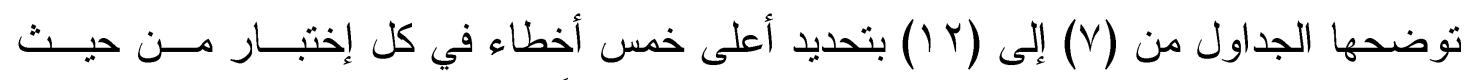

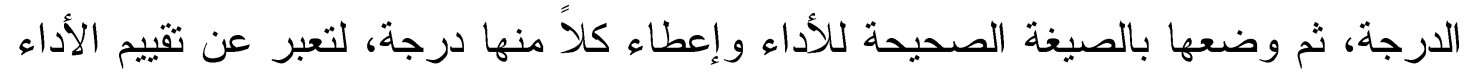

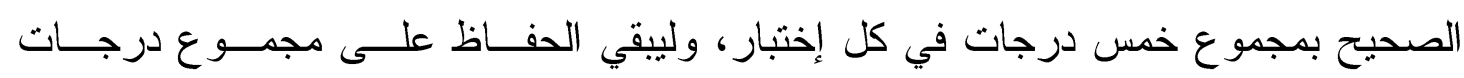

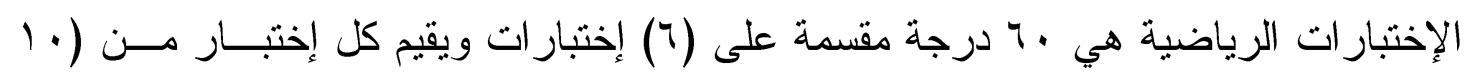

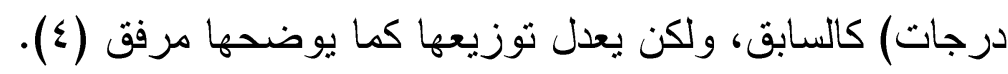




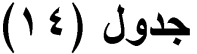

تعديل الجدول المعياري للإختبار ات قيا البحث من ( • (1) درجات إلى (0) درجات

\begin{tabular}{|c|c|c|c|c|c|c|c|c|c|c|c|c|c|c|c|c|c|}
\hline \multicolumn{3}{|c|}{ 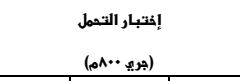 } & \multicolumn{3}{|c|}{ 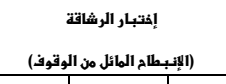 } & \multicolumn{3}{|c|}{ 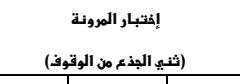 } & \multicolumn{3}{|c|}{ (الوثب العريخر من الثبات) } & \multicolumn{3}{|c|}{ 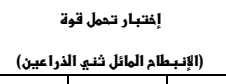 } & \multicolumn{3}{|c|}{ 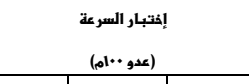 } \\
\hline المعدلة & المعيارية & ز ز ث & المعدلة & المعيارية & عدد & المعلة & المعيارية & مساقة & المعلة & المعيارية & مساقة & المعلة & المعيارية & عدد & المعدلة & المعيارية & بالثواني \\
\hline 5 & 10 & $2.55 \geq$ & 5 & 10 & $40 \leq$ & 5 & 10 & $30 \leq$ & 5 & 10 & $240 \leq$ & 5 & 10 & $20 \leq$ & 5 & 10 & 12.32 \\
\hline 4.75 & 9.5 & 2.58 & 4.75 & 9.5 & 38 & 4.75 & 9.5 & 27 & 4.75 & 9.5 & 235 & 4.75 & 9.5 & 19 & 4.75 & 9.5 & 12.5 \\
\hline 4.5 & 9 & 3.1 & 4.5 & 9 & 36 & 4.5 & 9 & 24 & 4.5 & 9 & 230 & 4.5 & 9 & 18 & 4.5 & 9 & 12.7 \\
\hline 4.25 & 8.5 & 3.4 & 4.25 & 8.5 & 34 & 4.25 & 8.5 & 21 & 4.25 & 8.5 & 225 & 4.25 & 8.5 & 17 & 4.25 & 8.5 & 12.9 \\
\hline 4 & 8 & 3.8 & 4 & 8 & 32 & 4 & 8 & 18 & 4 & 8 & 220 & 4 & 8 & 16 & 4 & 8 & 13.1 \\
\hline 3.75 & 7.5 & 3.11 & 3.75 & 7.5 & 30 & 3.75 & 7.5 & 15 & 3.75 & 7.5 & 215 & 3.75 & 7.5 & 15 & 3.75 & 7.5 & 13.3 \\
\hline 3.5 & 7 & 3.15 & 3.5 & 7 & 28 & 3.5 & 7 & 12 & 3.5 & 7 & 210 & 3.5 & 7 & 14 & 3.5 & 7 & 13.5 \\
\hline 3.25 & 6.5 & 3.18 & 3.25 & 6.5 & 26 & 3.25 & 6.5 & 9 & 3.25 & 6.5 & 205 & 3.25 & 6.5 & 13 & 3.25 & 6.5 & 13.7 \\
\hline 3 & 6 & 3.21 & 3 & 6 & 24 & 3 & 6 & 6 & 3 & 6 & 200 & 3 & 6 & 12 & 3 & 6 & 13.9 \\
\hline 2.75 & 5.5 & 3.24 & 2.75 & 5.5 & 22 & 2.75 & 5.5 & 3 & 2.75 & 5.5 & 195 & 2.75 & 5.5 & 11 & 2.75 & 5.5 & 14.1 \\
\hline 2.5 & 5 & 3.28 & 2.5 & 5 & 20 & 2.5 & 5 & 0 & 2.5 & 5 & 190 & 2.5 & 5 & 10 & 2.5 & 5 & 14.3 \\
\hline 2.25 & 4.5 & 3.31 & 2.25 & 4.5 & 18 & 2.25 & 4.5 & -3 & 2.25 & 4.5 & 185 & 2.25 & 4.5 & 9 & 2.25 & 4.5 & 14.5 \\
\hline 2 & 4 & 3.35 & 2 & 4 & 16 & 2 & 4 & -6 & 2 & 4 & 180 & 2 & 4 & 8 & 2 & 4 & 14.7 \\
\hline 1.75 & 3.5 & 3.38 & 1.75 & 3.5 & 14 & 1.75 & 3.5 & -9 & 1.75 & 3.5 & 175 & 1.75 & 3.5 & 7 & 1.75 & 3.5 & 14.9 \\
\hline 1.5 & 3 & 3.41 & 1.5 & 3 & 12 & 1.5 & 3 & -12 & 1.5 & 3 & 170 & 1.5 & 3 & 6 & 1.5 & 3 & 15.1 \\
\hline 1.25 & 2.5 & 3.45 & 1.25 & 2.5 & 10 & 1.25 & 2.5 & -15 & 1.25 & 2.5 & 165 & 1.25 & 2.5 & 5 & 1.25 & 2.5 & 15.3 \\
\hline 1 & 2 & 3.48 & 1 & 2 & 8 & 1 & 2 & -18 & 1 & 2 & 160 & 1 & 2 & 4 & 1 & 2 & 15.5 \\
\hline 0.75 & 1.5 & 3.52 & 0.75 & 1.5 & 6 & 0.75 & 1.5 & -21 & 0.5 & 1 & 155 & 0.75 & 1.5 & 3 & 0.75 & 1.5 & 15.7 \\
\hline 0.5 & 1 & 3.55 & 0.5 & 1 & 4 & 0.5 & 1 & -24 & 0 & 0 & 150 & 0.5 & 1 & 2 & 0.5 & 1 & 15.9 \\
\hline 0.25 & 0.5 & 3.58 & 0.25 & 0.5 & 2 & 0.25 & 0.5 & -27 & & & & 0.25 & 0.5 & 1 & 0.25 & 0.5 & 16.3 \\
\hline 0 & 0 & 4.2 & 0 & 0 & 0 & 0 & 0 & -30 & & & & 0 & 0 & 0 & 0 & 0 & 16.6 \\
\hline
\end{tabular}

قام الباحث بعرض النموذج المقتر ح لتقييم الإختبار ات على الخبــر اء عينــة البحــث

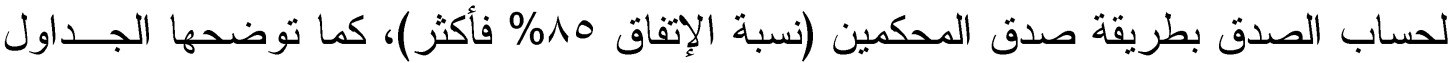

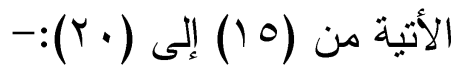

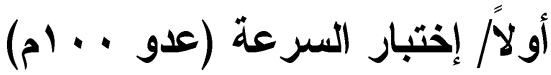

\section{جدول (10)}

\begin{tabular}{|c|c|c|c|c|c|}
\hline 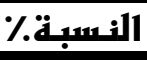 & الموافقة & الدرجة & نقييم إذتبار السر عة (عدو •-1م) & & \\
\hline $1 \ldots$ & $r$. & 1 & الكتق مسترخية و غير مشدودة & 1 & \multirow{5}{*}{ 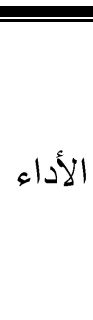 } \\
\hline $1 \ldots$ & r. & 1 & 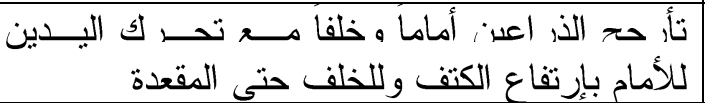 & r & \\
\hline 9. & 11 & 1 & المد الكامل لرجل الإسناد الخلفية & r & \\
\hline $1 \ldots$ & $r$. & 1 & دفع الأرض بمشط القدم ل & $\varepsilon$ & \\
\hline $1 \ldots$ & $r$. & 1 & الجري في الحارة المخصصة للمتسابق & 0 & \\
\hline $1 \ldots$ & $r$. & 0 & \multicolumn{2}{|l|}{ أقل زمن بالثانية } & الهدف \\
\hline $9 \wedge . r$ & 111 & 1. & \multicolumn{3}{|c|}{ المجمو ع الكلى } \\
\hline
\end{tabular}

مجلة أسيوط لعلوم وفنون التربية الرياضية 
يوضتح جدول (0) صدق تقييم إختبار السرعة حيث ثراوحت نســبة الإتفــاق بـين

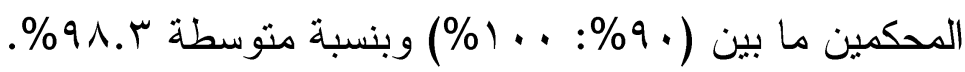

ثانياً/ إختبار تحمل القوة (الإنبطاح المائل ثني الأراعين)

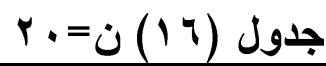

\begin{tabular}{|c|c|c|c|c|c|}
\hline 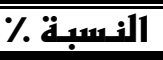 & الموافقة & الدرجة & يار تحمل القوة (الإنبـطاح المائل ثنـــ الذراعين) & 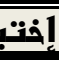 & تقبيـه \\
\hline$\overline{1 \ldots}$ & $\overline{T .}$. & 1 & إستقامة الجذع مع الر أس و الرجلين و عدم تقوس الجسم & $\overline{11}$ & \multirow{5}{*}{ الأداء } \\
\hline 90 & 19 & 1 & الألسافة بين الذزر اعين بإتساع الصدر & r & \\
\hline $1 \cdots$ & r. & 1 & إمتداد الذر اعين بالكامل أثناء الدفع & $\mu$ & \\
\hline $1 \cdots$ & r. & 1 & ثتى الذر اعين حتى يلامس الصدر الأرض أثناء الهبوط & $\varepsilon$ & \\
\hline 90 & 19 & 1 & تلاصق القدمين & 0 & \\
\hline $1 \cdots$ & r. & 0 & عدد & آكبر & 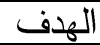 \\
\hline $9 \Lambda . \mu$ & 111 & 1. & \multicolumn{3}{|r|}{ 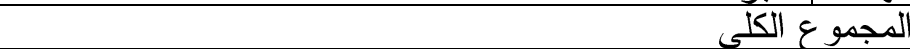 } \\
\hline
\end{tabular}

يوضتح جدول (7 (1) صدق تقييم إختبار تحمل القوة حيث تراوحت نسبة الإتفاق بـين

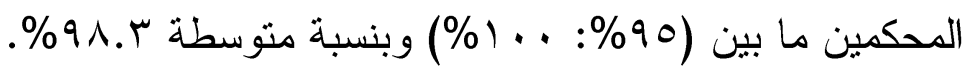

ثالثاً إختبار القدرة (الوثب العريض من الثبات) لئن

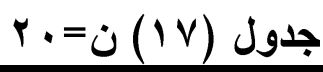

\begin{tabular}{|c|c|c|c|c|c|}
\hline 11انسبة. & الموافقة & الدروةة & \multicolumn{3}{|l|}{ تنقي_يم إفتبار القدرة (الوثب العريضر من الثبات) } \\
\hline 90 & 19 & 1 & 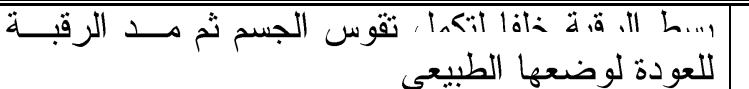 & 1 & \multirow{5}{*}{ 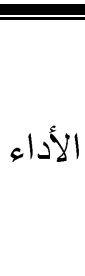 } \\
\hline 9. & 11 & 1 & تقارب الكتفين وتوسع الصدر أثناء الطير ان & r & \\
\hline $1 \ldots$ & r. & 1 & تقوس الجذع خلفا أثناء الطيران & r & \\
\hline $1 \ldots$ & $r$. & 1 & ميل الجذغ للأمام أثناء الهبوط & $\varepsilon$ & \\
\hline 9. & 11 & 1 & تباعد الكتفين وضم الصدر للأمام أثناء الهيوط & 0 & \\
\hline $1 \ldots$ & $r$. & 0 & 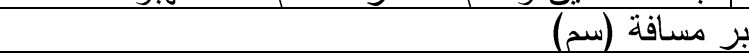 & أكبر & الهذف \\
\hline 90.1 & 110 & 1. & & 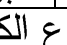 & \\
\hline
\end{tabular}

يوضتح جدول (IV) صدق تقييم إختبار القدرة حبث تراوحت نســبة الإتقــاق بـين

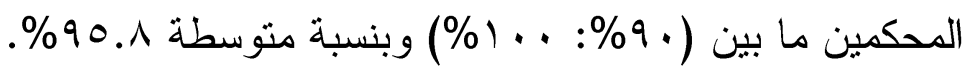

رابعاً/ إختبار المرونة (ثني الجذع من الوقوف) لين

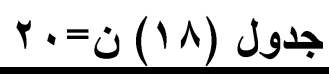

\begin{tabular}{|c|c|c|c|c|c|}
\hline \% & المواهُقة & الدرجة & \multicolumn{3}{|l|}{ تقبيـم إفتبـار المرونة (ثنـي الجذع من الوقوف) } \\
\hline 10 & IV & 1 & النظر لأسفل بين الذر اعين & 1 & \multirow{5}{*}{ 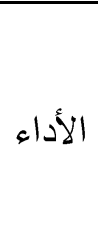 } \\
\hline $1 \cdots$ & r. & 1 & ثنى الجذع أقصى مدي ممكن أماما للأسفل & r & \\
\hline $1 \cdots$ & r. & 1 & ثبات الجذع عند أقصى مدي ممكن من الثنى & r & \\
\hline $1 \cdots$ & r. & 1 & الذر اعان على كامل إمتذادهما للأسفل أقصى مدي ممكن & $\varepsilon$ & \\
\hline $1 \ldots$ & $r$ r. & 1 & عدم ثنى الركبتين عبن & 0 & \\
\hline $1 \cdots$ & r. & 0 & بر مسافة (سم) & أكبر & الهرف \\
\hline $9 V .0$ & $11 \mathrm{~V}$ & 1. & & 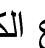 & المجمو \\
\hline
\end{tabular}

مجلة أسيوط لعلوم وفنوز التربية الرياضية 


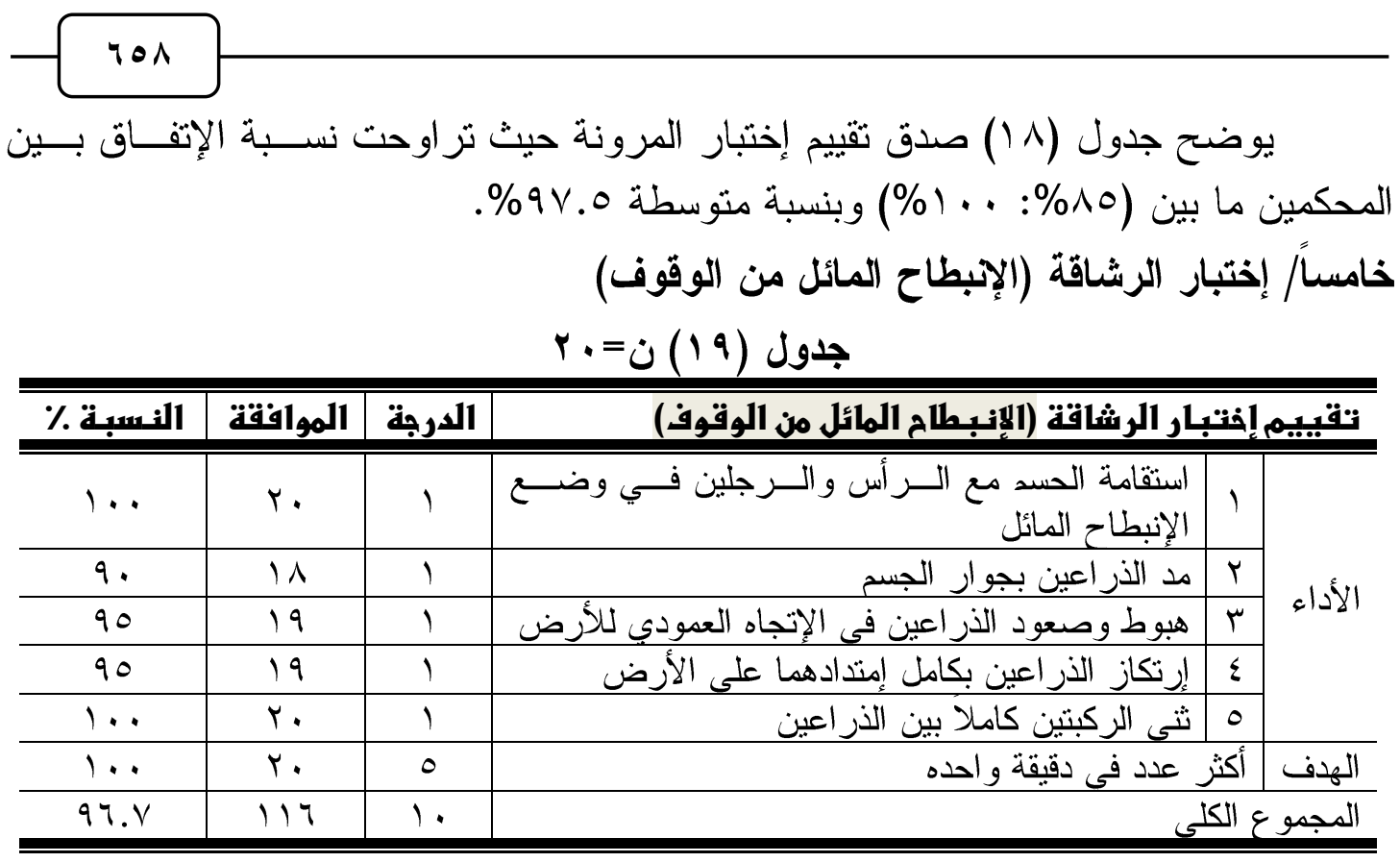

يوضتح جدول (9 (1) صدق تقييم إختبار الرشاقة حيث تراوحت نسـبة الإتفـاق بـين

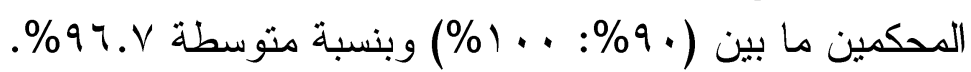

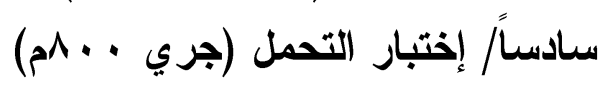

$$
\text { جدول (r) }
$$

\begin{tabular}{|c|c|c|c|c|c|}
\hline 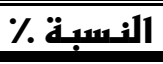 & الموافقة & الدروجة & 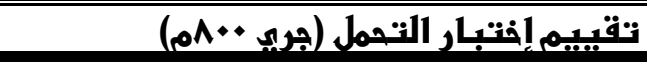 & & \\
\hline 9. & 11 & 1 & النظر للأمام في إتجاه الجري & 1 & \multirow{5}{*}{ 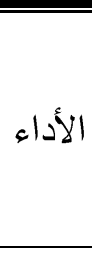 } \\
\hline 9. & 11 & 1 & يشكل مفصل الكو عز اوية · 9 درجة باستمر ار & $r$ & \\
\hline 90 & 19 & 1 & الهجوم على خط النهاية بأقصى سرعه & $\mu$ & \\
\hline 9. & 11 & 1 & الدخول في الحارة الأولى فى الوقت المناسب & $\varepsilon$ & \\
\hline 9. & 11 & 1 & لتجاوز المنافس من الحافة الخارجية للمضمار & 0 & \\
\hline $1 \ldots$ & $r$. & 0 & \multicolumn{2}{|l|}{ أقل زمن بالثانية } & الهدف \\
\hline 94.0 & 111 & 1. & \multicolumn{3}{|c|}{ المجمو ع الكلى } \\
\hline
\end{tabular}

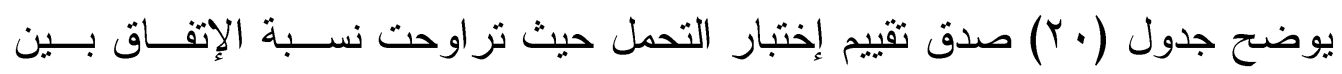

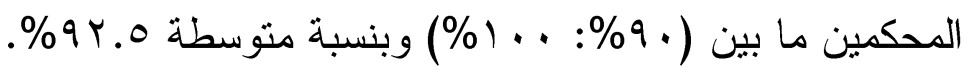

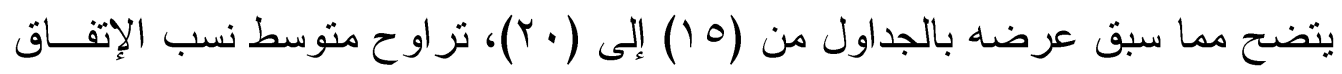

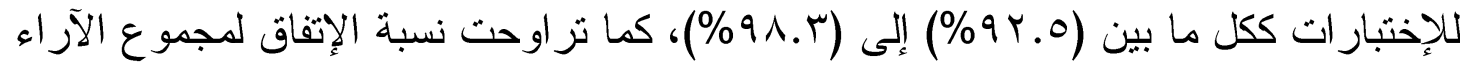

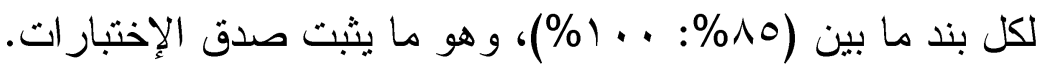
الثبات.

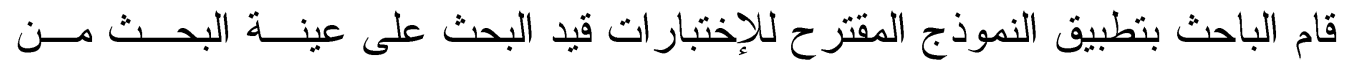

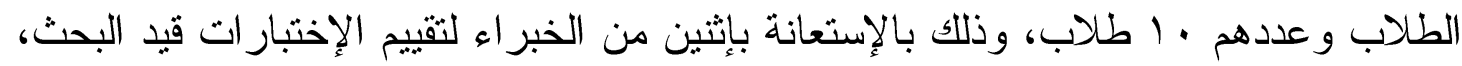

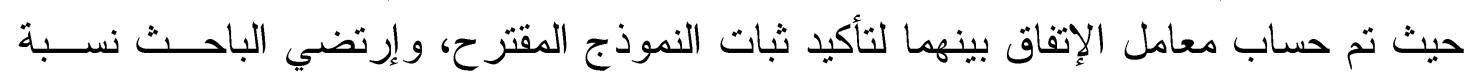
إتفاق 0^\% فأكثر بدلالة كوبر لتأكيد ثبات النموذج المقترح، كما يوضحها جدول (Y). مجلة أسيوط لعلوم وفنوز التربية الرياضية 


\begin{tabular}{|c|c|c|c|c|c|c|c|c|c|c|c|c|c|}
\hline \multirow[b]{2}{*}{ المتو سط } & \multirow[b]{2}{*}{ المجموع } & \multicolumn{10}{|c|}{ أفراد العينة ن= •1 } & \multirow{2}{*}{ ن الخبر اء } & \multirow{2}{*}{$\begin{array}{r}\text { (ך) بلإختبار } \\
\text { بنود }\end{array}$} \\
\hline & & 1. & 9 & $\wedge$ & v & 1 & $\circ$ & $\varepsilon$ & r & r & 1 & & \\
\hline- & 00 & 7 & 0 & 0 & 1 & $\circ$ & 7 & 7 & 0 & 7 & $\circ$ & 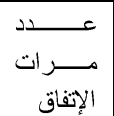 & \multirow{3}{*}{ السرعة } \\
\hline- & $\circ$ & - & 1 & 1 & - & 1 & - & - & 1 & - & 1 & 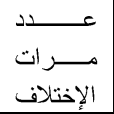 & \\
\hline$\% 91 . \vee$ & - & $\% 1 \ldots$ & $\% \wedge r . r$ & $\% \wedge r . r$ & $\% 1 \ldots$ & $\% \wedge r . r$ & $\% 1 \ldots$ & $\% 1 \ldots$ & $\% \wedge r . r$ & $\% 1 \ldots$ & $\% \wedge$ \%.r & نالتفاق بــة & \\
\hline- & or & 1 & 1 & 0 & 7 & 1 & 0 & 7 & 0 & 7 & 7 & لالإتفاق & \multirow{3}{*}{ تحوة تحــلـل } \\
\hline- & $r$ & - & - & 1 & - & - & 1 & - & 1 & - & - & مستـرات & \\
\hline$\% 9 \leq .9$ & - & $\% 1 \ldots$ & $\% 1 \ldots$ & $\% \wedge r . r$ & $\% 1 \ldots$ & $\% 1 \ldots$ & $\%$ \%н.r. & $\% 1 \ldots$ & $\% \wedge r . r$ & $\% 1 \ldots$ & $\% 1 \ldots$ & نالإتفاق بـــة & \\
\hline- & 00 & 0 & 1 & 1 & 0 & 1 & $\circ$ & 。 & 7 & 0 & 7 & لالإتفاق & \multirow{3}{*}{ القدرة } \\
\hline- & 0 & 1 & - & - & 1 & - & 1 & 1 & - & 1 & - & 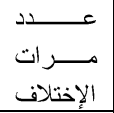 & \\
\hline$\% 91 . \vee$ & - & $\%$ \%रr.r & $\% 1 \ldots$ & $\% 1 \ldots$ & $\% \wedge r . r$ & $\% 1 \ldots$ & $\% \wedge r . r$ & $\% \wedge r . r$ & $\% 1 \ldots$ & $\% \wedge r . r$ & $\% 1 \ldots$ & نالتفاق بــة & \\
\hline- & 01 & 1 & 0 & 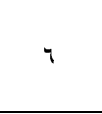 & ร & 1 & 1 & 0 & 1 & 7 & 7 & لالإتفاق & \multirow{3}{*}{ المرونة } \\
\hline- & r & - & 1 & - & - & - & - & 1 & - & - & - & مـــــــــدات & \\
\hline \%१५. & - & $\% 1 \ldots$ & \%^r.r & $\% 1 \ldots$ & $\% 1 \ldots$ & $\% 1 \ldots$ & $\% 1 \ldots$ & \%Аr.r & $\% 1 \ldots$ & $\% 1 \ldots$ & $\% 1 \ldots$ & نالتفاق بـة & \\
\hline- & $0 \leqslant$ & 0 & 7 & 0 & 7 & 0 & 0 & 7 & 0 & 0 & 7 & عـــــــــد & \multirow{3}{*}{ الرشاقة } \\
\hline- & 7 & 1 & - & 1 & - & 1 & 1 & - & 1 & 1 & - & 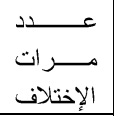 & \\
\hline$\% \wedge 9.9$ & - & \%^r.r & $\% 1 \ldots$ & \%入r.r & $\% 1$. & \%Аr.r & \%Аr.r & $\% 1 \ldots$ & \%ᄉr.r & \%лr.r & $\% 1 .$. & نالنفـــــة & \\
\hline- & 00 & 0 & 7 & 。 & 。 & 。 & 1 & 1 & 1 & 。 & 7 & عـــــــــد & \multirow{3}{*}{ التحمل } \\
\hline- & 0 & 1 & - & 1 & 1 & 1 & - & - & - & 1 & - & 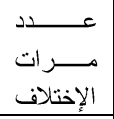 & \\
\hline$\%$ \%).V & - & \%Аr.r & $\% 1 \ldots$ & \%یr.r & \%Аr.r & $\% \wedge$ \%.r & $\% 1 \ldots$ & $\% 1 \ldots$ & $\% 1 \ldots$ & \%лr.r & $\% 1 .$. & نالنـــــــة & \\
\hline
\end{tabular}




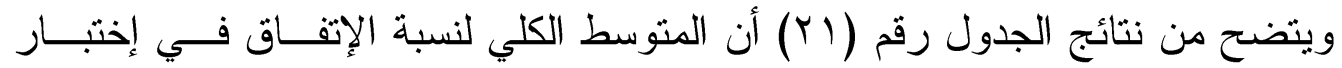

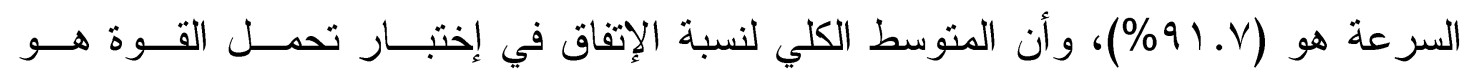

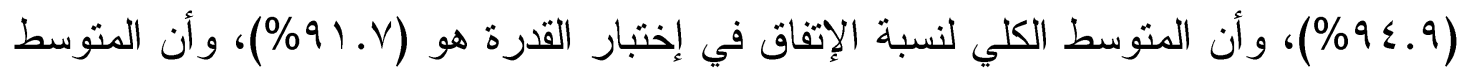

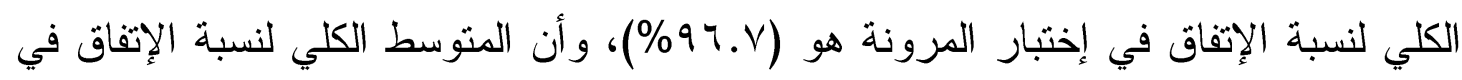

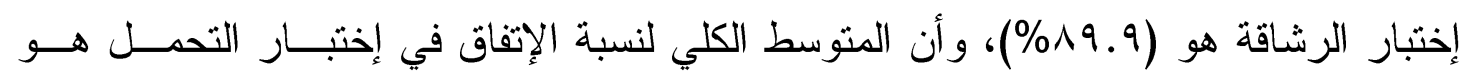

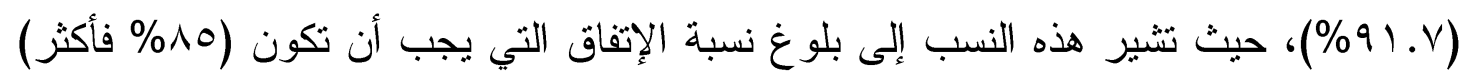

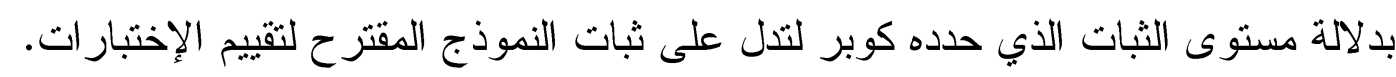

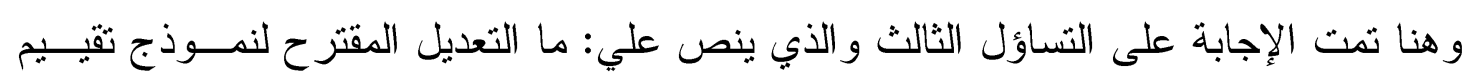

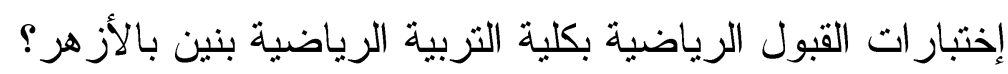

الإستنتاجات.

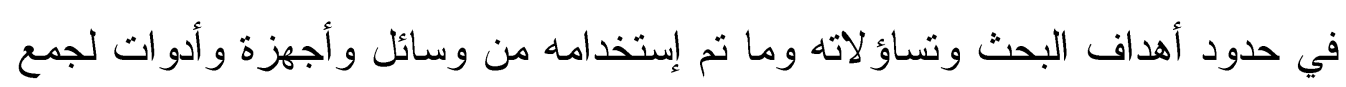
البيانات أمكن للباحث التوصل إلى الإستنتاجات الأتية:

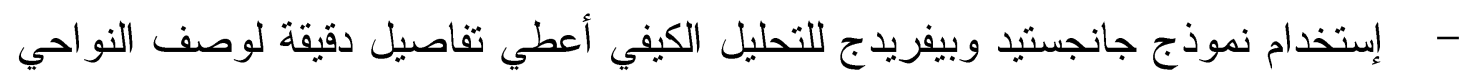

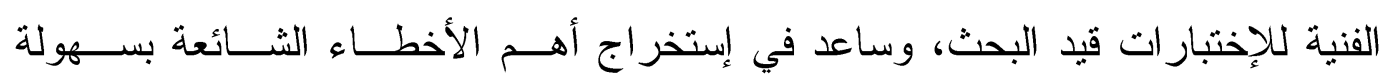

ووضوح.

- - الرجلان هما الأكثر أهمية في إختبار السرعة حيث حصلا على أكبر درجة بواقــع بـاه بنسبة . ب\% من درجة الأداء.

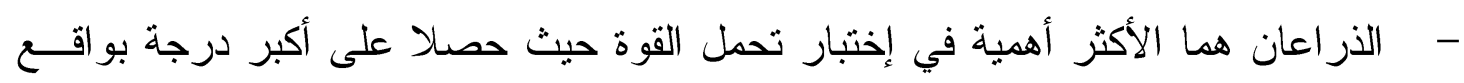

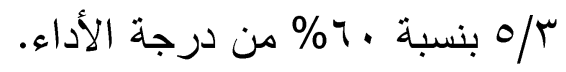

- - الجذع هو الأكثر أهمية في إختبار القدرة حيث الاداء حصل على أكبر درجة بواقع ع /ه بنسبة \% من من درجة الأداء.

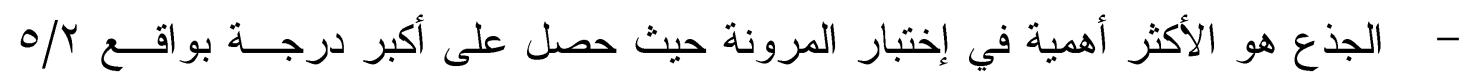

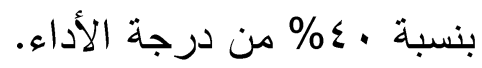

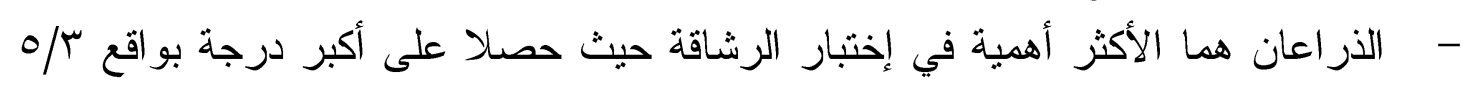
بنسبة . ب\% من درجة الأداء.

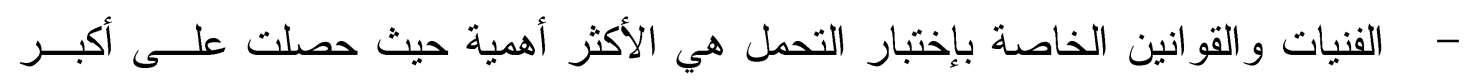

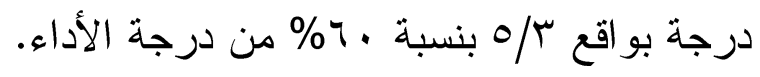

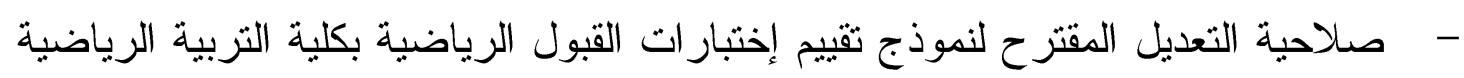

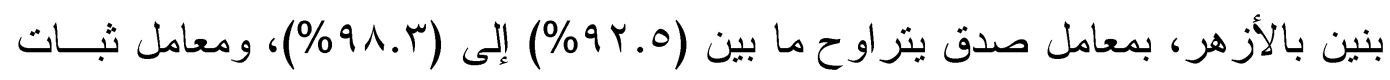

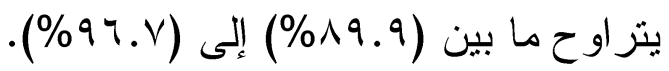




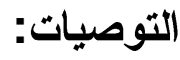

في حدود أهداف البحث وتساؤلاته وما تم التوصل إليه من نتائج يوصي الباحث بما يلي:

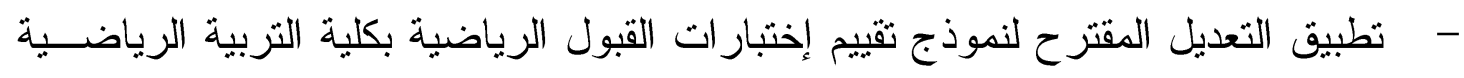
بنين بالأز هر.

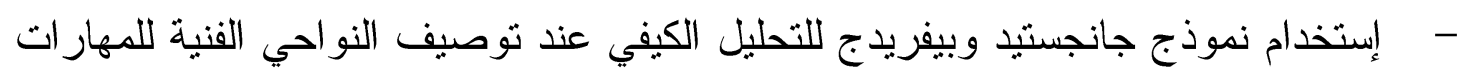
و إستخر اج أهم الأخطاء الثائعة لها.

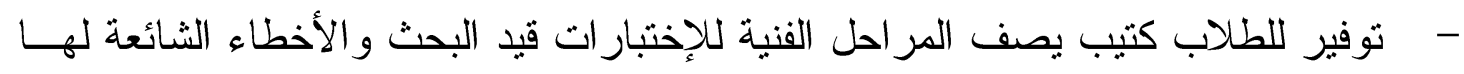
وقانونية أدائها ودرجات التقيبيم لها.

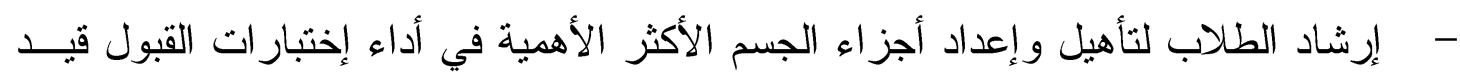
البحث.

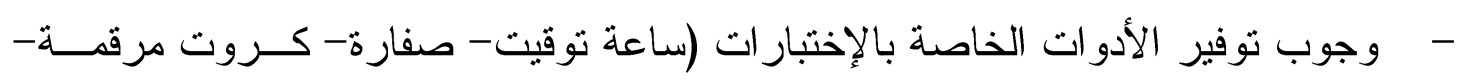

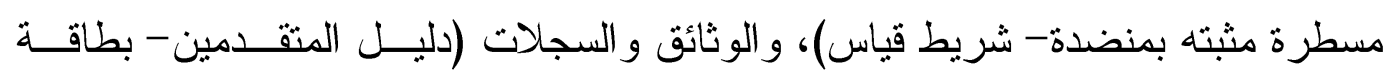

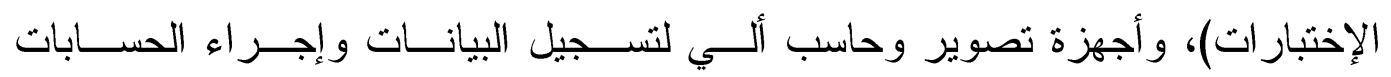
الإحصائية. - - زيادة عدد الممتحنين من أعضاء هيئة التدريس نظراً لصعوبة تقييم الأعداد الكبيرة مسن الطلاب التي تثقلم في الإختبارات.

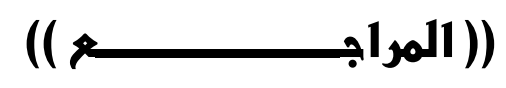

أولاً: المراجه العربية

1- السيد على شبيب: بناء مقياس لمهار ات التحليل الحركي الكيفي لدى مدربي الملاكمة،

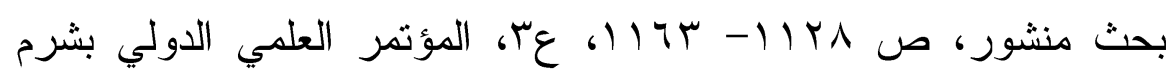
الثيخ (الرياضة جزء منتظم من نمط الحياة)، كلية التزبية الرياضية،

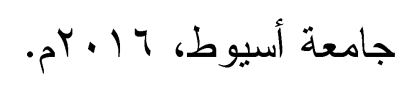

r- إيمان سيد أحمد، وآخرون:تقييم مستوي الأداء المهارى لـهارة الضربة الأمامية

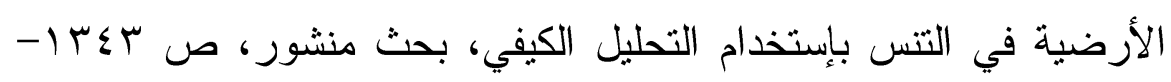

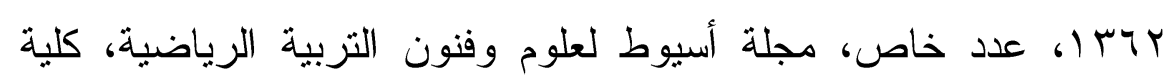

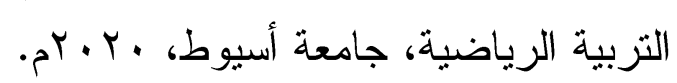

r- زكي محمد حسن: تطبيقات علم الحركة في النشاط الرياضي، المكتبة المصرية، القاهرة،

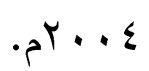


ع- طارق فاروق عبد الصمد: نظرية الخصائص الأساسية رؤية لتحليل المهارات، الدار

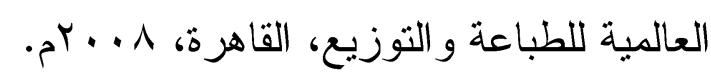

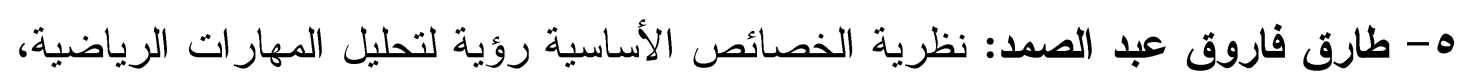
مطبعة جامعة أسيوط، جامعة أسيوط، 0 . . rم.

צ- طلحة حبين، وآخرون: التحليل الكيفي (مفهومه- تاريخه- نماذجه- مهامه- تطبيقاته)،

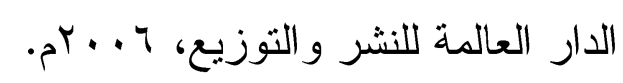

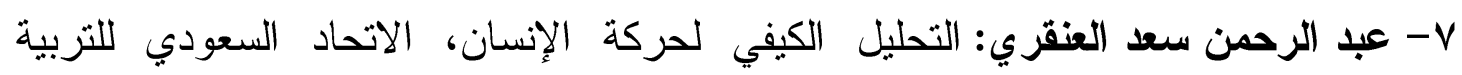

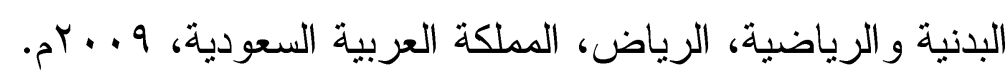

1- علي سلوم: الإختبار ات و القياس و الإحصاء في المجال الرياضي، الطيف للطباعة، جامعة الطيأ

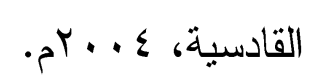

9- كمال عبد الحميد: أسس الحركة للإنسان في الحباة الرياضية، الطبعة الأولي، مركز

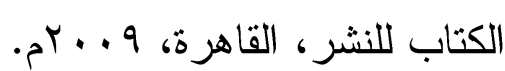

• 1 - ليلى السبد فرحات: القياس والإختبار في التربية الرياضية، الطبعة الثالثة، مركز الكتاب

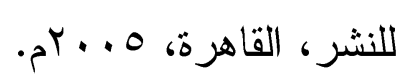

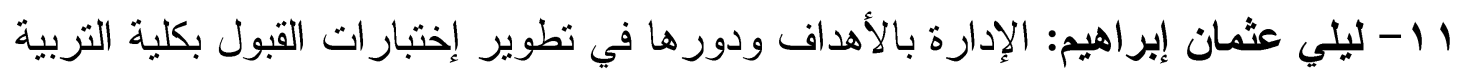

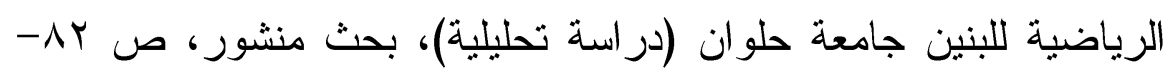

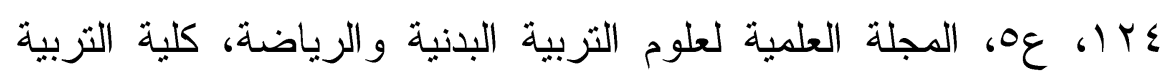

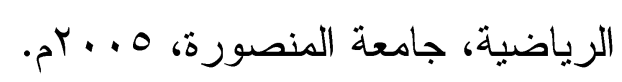

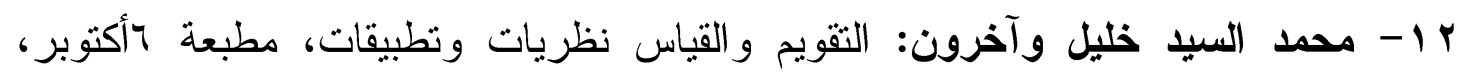

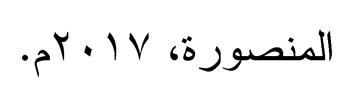

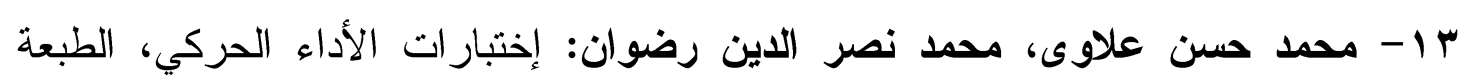

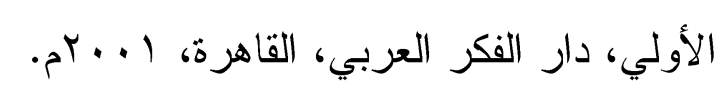

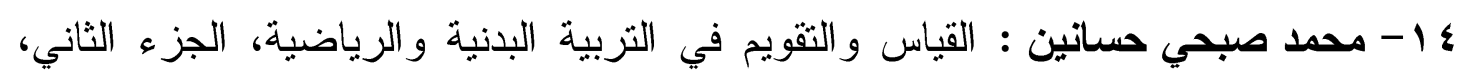

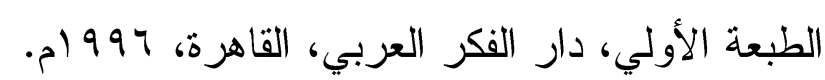

ه 1 - محمد ضاحي عباس: التحليل الكيفي لمهار ات الجمباز وفقاً للأوضاع الأساسية بإستخدام نموذج جانجستيد وبيفريدج كدالة لتقنين برنامج تدريبي مقترح لمبنتئي لهئي

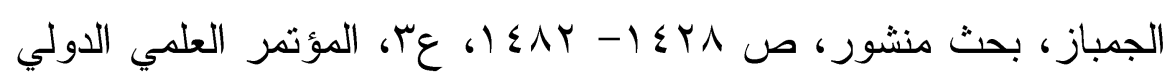


بشرم الثيخ (الرياضة جزء منتظم من نمط الحياة)، كلية التربية الرياضية،

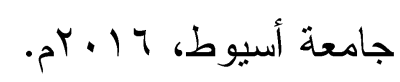

14- محمد محمد عبد العزيز: إستخدام بعض نماذج التحليل الحركي الكيفي المدعوم

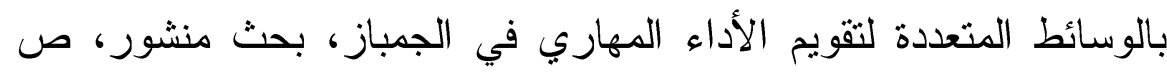
(90-9 90

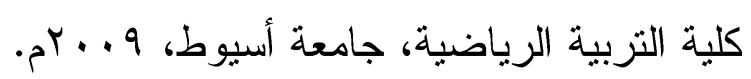

IV

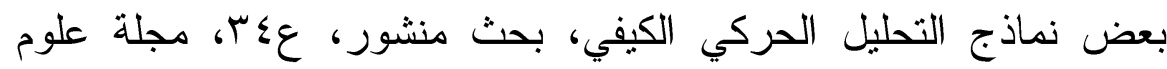
الرياضة دورية علمية محكمة، كلية التربية الرياضية، جامعة المنيا،

$$
\text { . }
$$

1 - هبة محمود حمدي : در اسة تحليلية لتقييم الأداء الفني لبعض مهار ات الجمباز بإستخدام

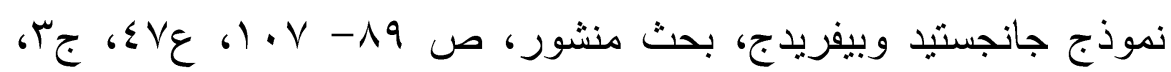

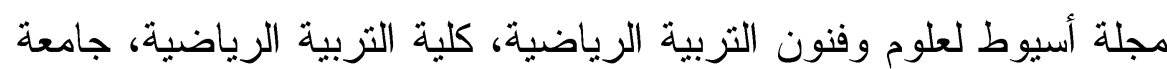

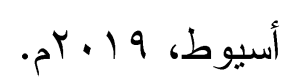

9 1 - وديع محمد مرسي : تأثير تمرينات خاصة بدلالة التحليل الكيفي لحركة مسك الذراع

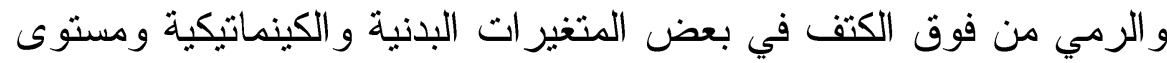

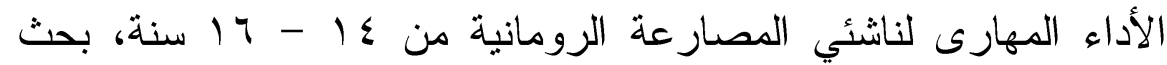

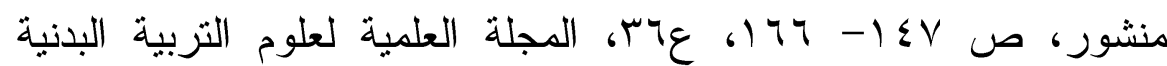

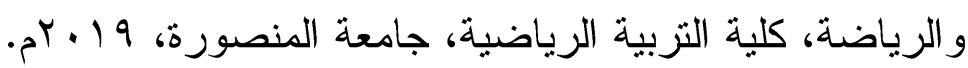

\section{ثانباً: المراجم الأجنببة الرياضة}

20- Brian Mackenzie: 101 Performance Evaluation Tests, Jonathan Pye, Electric Word plc 67-71 Goswell Road, London EC1V 7EP, 2005.

21- Carling C, Reilly T. \& Williams AM: Performance Assessment for Field Sports, 1st, ed., Routledge, Taylor \& Francis, New York, 2009.

22- Hall S: Basic Biomechanics, 6th., ed., McGraw -Hill Education, London, 2011. 
23- Marek Walisiewicz, Maddy King: Strength Training the Complete Step-by-Step Guide to a Stronger, Sculpted Body, First American Edition, 2009, Published in the United States by DK Publishing

24- Hudson Street New York, New York 1TD444, December/2009. Staff What Is Evaluation?". International Center for Alcohol Policies - Analysis. Balance. Partnership. International Center for Alcohol Policies. Archived from the original on 2012-05-04. Retrieved 13 May 2012.

نالثاً: المراجم الإلكترونبية

25- www.azhar.edu.eg 